\title{
17. CLAY MINERALOGY OF DEEP-SEA SEDIMENTS IN THE NORTHWESTERN PACIFIC, DSDP, LEG 20
}

\author{
Hakuyu Okada and Katsutoshi Tomita, Department of Geology, Kagoshima University, \\ Kagoshima 890, Japan
}

\section{INTRODUCTION}

Clay mineral study of samples collected during Leg 20 of the Deep Sea Drilling Project in the western north Pacific was carried out mainly by means of X-ray diffraction analyses. Emphasis was placed on determining vertical changes in mineral composition of sediments at each site.

Results of the semiquantitative and quantitative determinations of mineral compositions of analyzed samples are shown in Tables $1,2,3,5$, and 7. The mineral suites presented here show some unusual characters as discussed below. The influence of burial diagenesis is also evidenced in the vertical distribution of some authigenic minerals.

These results may contribute to a better understanding of deep-sea sedimentation on the northwestern Pacific plate.

\section{ANALYTICAL PROCEDURES}

Each sample was dried in air, and X-ray diffraction patterns were obtained using aggregates on glass slides. The clay minerals were identified as follows:

1) X-ray analysis: (a) untreated, (b) treated with ethylene glycol, and (c) heated for 1 hour at each of the following temperatures: $300^{\circ} \mathrm{C}, 500^{\circ} \mathrm{C}$, and $600^{\circ} \mathrm{C}$. In each case X-ray examination was performed at room temperature immediately upon cooling.

2) Differential thermal analysis for selected samples.

3) Electron microprobe X-ray analyses by the Shimadzu-ARL Electron Microprobe X-Ray Analyzer EMX-SM for selected samples.

\section{Intensity Ratios of Basal Reflections of Clay Minerals}

In the case where principal basal reflections of clay minerals do not overlap with one another, it is easy to obtain the intensity ratio of reflections. When a specimen has a complex clay-mineral composition, the reflections of respective clay minerals sometimes overlap. In such cases, the specimen must be treated either thermally or chemically to eliminate or move X-ray reflections of certain minerals, so that the reflection intensity of individual minerals can be obtained.

When montmorillonite and chlorite coexist in one specimen and the (001) reflections of both minerals overlap with each other, the reflection intensity of each mineral cannot be obtained without any treatment. In this case, by heating the specimen at $300^{\circ} \mathrm{C}$, the $15 \AA$ reflection of montmorillonite is moved to 9 to $10 \AA$, and the intensity of the (001) reflection of chlorite is obtained. Treatment with ethylene glycol or glycerol usually shifts the reflection of montmorillonite from $15 \AA$ to $17 \AA$. The $(001)$ reflection intensity of montmorillonite can be obtained by subtracting the (001) reflection intensity of chlorite from the preheating or pretreating reflection intensity at $15 \AA$.

In a specimen with coexisting kaolinite and chlorite, their overlapping reflections make it difficult to determine quantitatively these mineral compositions. For such specimens Wada's method (Wada, 1961) and heat treatment were adopted.

The following shows examples of the determination of some intensity ratios of reflections of clay minerals.

\section{Case 1}

Montmorillonite (two layers of water molecules between silicate layers)-kaolinite mixture.

This is the situation in which samples contain both montmorillonite and kaolinite. The first-order basal reflections of these minerals do not overlap. When the (002) reflection of montmorillonite, which appears at about $7 \AA$, is absent or negligible, the intensity ratio is easily obtained. As the reflections at $15 \AA$ and $7 \AA$ are the first-order ones of montmorillonite and kaolinite, respectively, the intensity ratio of these minerals is as follows:

$$
I(\text { montmorillonite }): I(\text { kaolinite })=I(15 \AA): I(7 \AA) \text {. }
$$

In the presence of the (002) reflection of montmorillonite, the sample must be heated at about $300^{\circ} \mathrm{C}$ or treated with ethylene glycol or glycerol before X-ray diffraction analyses. In the case of heating, the intensity ratio of montmorillonite and kaolinite is $I(10 \AA)$ : $I(7 \AA)$. In the case of treating with ethylene glycol, the ratio is $I(17$ $\AA): I(7 \AA)$.

\section{Case 2}

Montmorillonite (one layer of water molecules between silicate layers)-kaolinite mixture.

The intensity ratio of basal reflections of montmorillonite and kaolinite is given by

$$
I(\text { montmorillonite }): I(\text { kaolinite })=I(12.5 \AA): I(7 \AA) \text {. }
$$

In the case of treatment with ethylene glycol, the ratio is $I(17 \AA): I(7 \AA)$.

\section{Case 3}

Illite-kaolinite mixture.

The intensity ratio of basal reflections of illite and kaolinite is written as

$$
I(\text { illite }): I(\text { kaolinite })=I(10 \AA): I(7 \AA) .
$$




\section{Case 4}

Montmorillonite (one layer of water molecules between silicate layers)-illite-kaolinite mixture.

The intensity ratio of these minerals is as follows:

$$
\begin{gathered}
I(\text { montmorillonite }): I(\text { illite }): I(\text { kaolinite })= \\
I(12.5 \AA): I(10 \AA): I(7 \AA) .
\end{gathered}
$$

In the case of treatment with ethylene glycol, the ratio becomes

$$
\begin{gathered}
I(17 \AA): I(10 \AA): I(7 \AA) . \\
\text { Case } 5
\end{gathered}
$$

Montmorillonite (two layers of water molecules between silicate layers)-illite-kaolinite mixture.

The intensity of these minerals is determined after treatment with ethylene glycol. The intensity ratio of these minerals is

$$
\begin{gathered}
I(\text { montmorillonite }): I(\text { illite }): I(\text { kaolinite })= \\
I(17 \AA): I(10 \AA): I(7 \AA) .
\end{gathered}
$$

\section{Quantitative Features of the Clays}

Measurements of peak intensities from X-ray powder patterns were carried out using a planimeter. The area of the peak was taken as the intensity of reflection.

Powdered specimens were placed on a glass slide and mixed into a suspension with drops of water. The suspension was then spread over the slide to cover about $2.7 \times 2.0$ $\mathrm{cm}$ and dried at room temperature without disturbance. Clay films with insofar as possible reproducible uniformity, with respect to the state of aggregation of clay powders, were used for relative determinations of clay-mineral contents. The clay film was then irradiated with X-rays using a $1^{\circ}-1^{\circ}-0.3 \mathrm{~mm}$ slit system.

Principal basal reflections dealt with were $15,12.5,10$, and $7 \AA$. Resolution of overlapping peaks preceded the quantitative determination. The estimation of hydrous mica proved rather difficult. In this case, the term "hydrous mica" is applied to materials such as complicated irregularly interstratified sequences of illite and montmorillonite layers. The $\mathrm{d}(001)$ of the hydrous mica is in the range of $10.3 \AA$ to $11 \AA$, and it is contracted to $10 \AA$ by heat treatment at $500^{\circ} \mathrm{C}$. It is not destroyed at $800^{\circ} \mathrm{C}$.

Quantitative clay mineralogical analyses were performed after Oinuma and Kobayashi's (1961) method. The calibration factor in obtaining relative amounts is the reciprocal of the reflection intensity ratio of respective clay minerals when they occur in equivalence. Therefore, the reflection intensity ratio is required for the quantitative determination of clay minerals. The ratio is affected by various factors such as particle size distribution, degree of parallel orientation of the clays, degree of crystallinity, and others. The first two can be controlled by preparation of sample powders in clay films or plates for X-ray diffraction. In regard to degree of crystallinity, it may be desirable to select the standard mineral which agrees with the mineral in the test sample. In this paper, we selected a considerable number of standard minerals of different modes of occurrence and various degrees of crystallinity. The standard samples used in this study are as follows-Kaolinite: Iriki Mine, Iriki, Kagoshima Prefecture, Japan; Illite: Iwato Mine, Makurazaki, Kagoshima Prefecture, Japan; Montmorillonite: Aterazawa, Yamagata Prefecture, Japan.

Relative intensity ratios of two kinds of clay minerals $\left(I_{A} / I_{B}\right)$ can be converted to ratios of relative amounts by multiplying $I_{A} / a: I_{B} / b$, where $a / b=$ intensity ratio of minerals $A$ and $B$ in equal amounts. Values of $a / b$ used in this study are: $M(17 \AA) / I(10 \AA) / K(7 \AA)=2.6 / 1.0 / 1.2 . M(17 \AA)$ is the intensity of the $17 \AA$ reflection of montmorillonite after treatment with ethylene glycol. $I(10 \AA)$ is the intensity of the $10 \AA$ reflection of illite. $K(7 \AA)$ is the intensity of the $7 \AA$ reflection of kaolinite.

\section{RESULTS}

\section{Site $194\left(33^{\circ} 58.66^{\prime} \mathrm{N}, 148^{\circ} 48.64^{\prime} \mathrm{E}\right)$}

This site is located on the abyssal floor east of the Japan Trench. The mineral compositions of the sediment at this site are shown in Table 1 and Figure 1. X-ray diffractograms show that the clay fractions consist mostly of a mixture of illite, kaolinite, quartz, feldspar, and amorphous silica. In addition, small amounts of montmorillonite were observed in a few samples. The relative proportion in amounts of illite and kaolinite is approximately 50\% to $60 \%$ for illite and $40 \%$ to $50 \%$ for kaolinite. In some samples (Sections 1-6 and 2-2), amorphous silica is dominant. Clinoptilolite is present in a sample of Section 1-3. The X-ray powder pattern of clinoptilolite is similar to that of heulandite, but the zeolite in the sample was confirmed as clinoptilolite by heat treatment, since heulandite structure is destroyed at $500^{\circ} \mathrm{C}$.

No significant compositional difference was observed between Quaternary and upper Miocene sediments.

\section{Site $195\left(32^{\circ} 46.40^{\prime} \mathrm{N}, 146^{\circ} 58.73^{\prime} \mathrm{E}\right)$}

This drill site is situated on the abyssal floor east of Izu-Bonin Trench. The 202-meter-long core is lithologically subdivided into two units; the upper unit, about 170 meters thick, is a diatomaceous, ash-rich clay of middle Miocene to Pleistocene age, and the lower unit consists of interbedded chalk, chert, and marl of Lower Cretaceous age.

The vertical mineral distributions at this site are shown in Table 2 and Figure 2. Illite and kaolinite are the principal minerals in the clay fractions of Core 1 . The ratio of these minerals is similar to that of Site 194. One selected sample $(195-1-6,23-24 \mathrm{~cm})$ rich in illite and kaolinite was analyzed by electron microprobe X-ray analyzer (Plates 1 and 2).

In Core 2 montmorillonite is found in addition to illite and kaolinite. Montmorillonite with one layer of water molecules between silica layers is present in the upper part of Core 2, while montmorillonite with two layers of water molecules was detected in the middle part of the same core. Further, in the lower part of Core 2, fresh biotite was found. Both quartz and feldspar are present through Cores 1 and 2 . In Core 3 calcite is dominant, but quartz occurs only in trace amounts. Chlorite is observable in a few samples from the upper sequence of this hole. 
TABLE 1

Results of X-Ray Diffraction Analyses, Hole 194

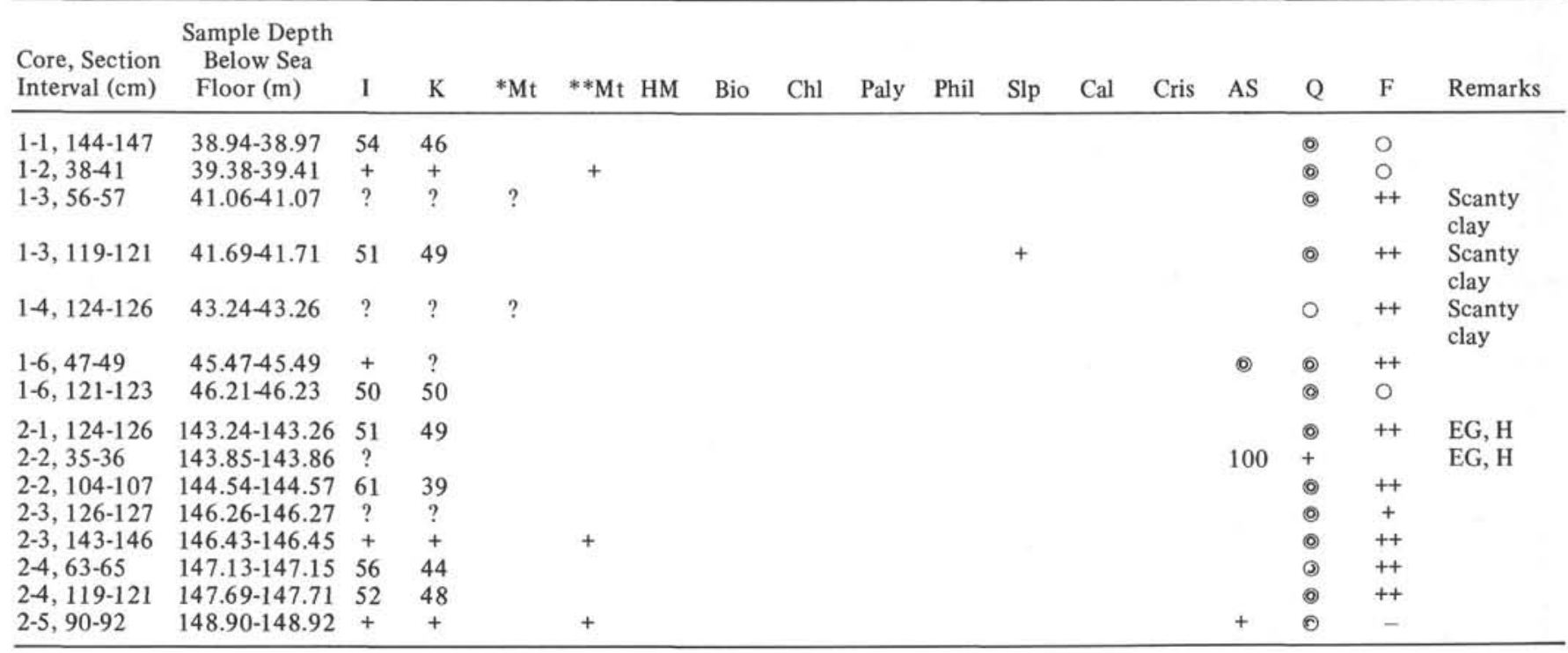

Note: The following abbreviations are used in Tables 1 to $9 . \mathrm{I}$ : illite, $\mathrm{K}$ : kaolinite, ${ }^{*} \mathrm{Mt}$ : montmorillonite with one layer of water molecules, **Mt: montmorillonite with two layers of water molecules, ( ): montmorillonite with mixed layers of water molecules, HM: hydrous mica, Bio: biotite, Chl: chlorite, Paly: palygorskite, Phil: phillipsite, Clp: clinoptilolite, Cal: calcite, Cris: cristobalite, AS: amorphous silica, Q: quartz, F: feldspar, EG: ethylene glycohol treatment, and $\mathrm{H}$ : heat treatment. $\odot$ : abundant, $\mathrm{O}$ : common, ++ : uncommon, $+:$ rare, $-:$ traceable.

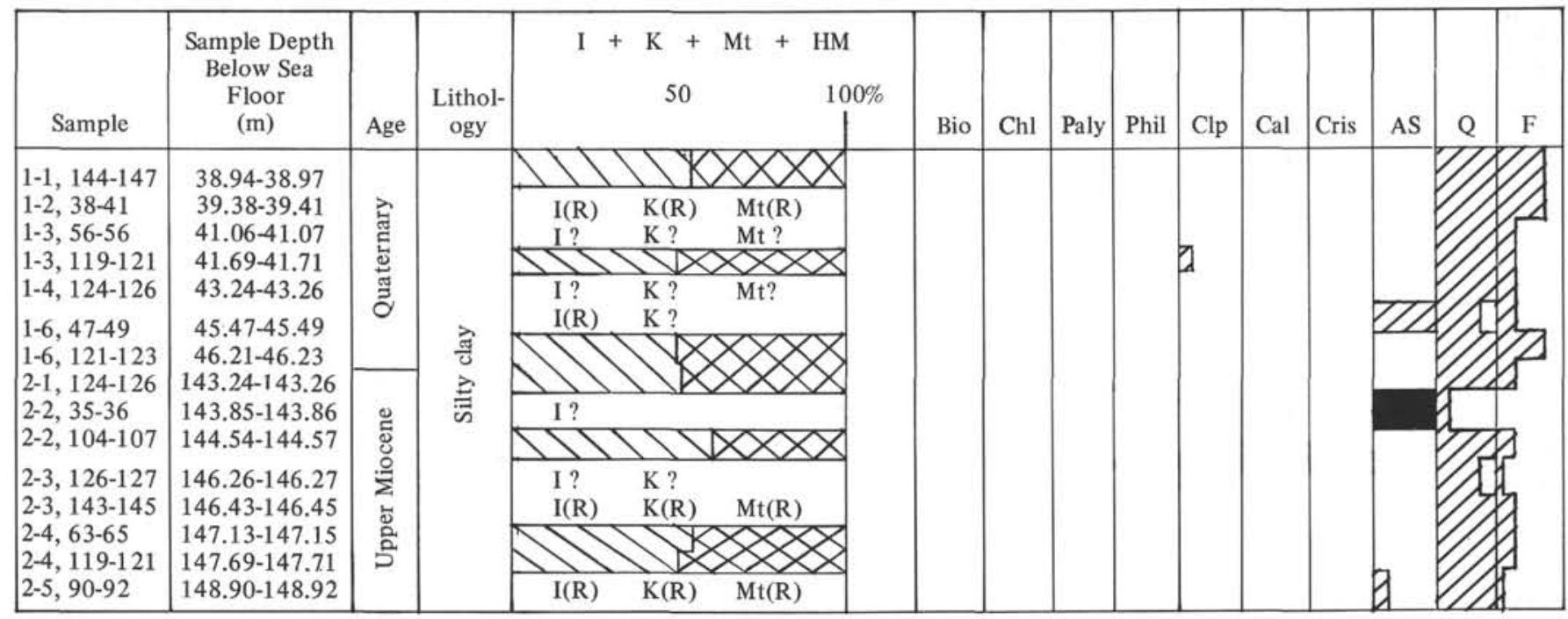

\section{LEGEND}

$\begin{array}{ll}\text { I: } & \text { illite } \\ \mathrm{K}: & \text { kaolinite } \\ \mathrm{Mt}: & \text { montmorillonite } \\ \mathrm{HM}: & \text { hydrous mica }\end{array}$

: almost $100 \%$

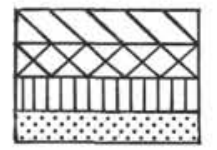

abundant (A)

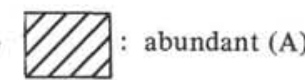

Bio: biotite, Chl: chlorite, Paly: palygorskite, Phil: phillipsite, Clp: clinoptilolite,

Cal: calcite, Cris: cristobalite, AS: amorphous silica, Q: quartz, F: feldspar

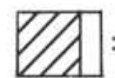

common (C)

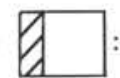

uncommon (U)
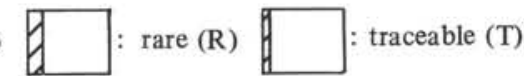

Figure 1. Variations in mineral composition of samples from Hole 194.

\section{Site $196\left(30^{\circ} 06.97^{\prime} \mathrm{N}, 148^{\circ} 34.49^{\prime} \mathrm{E}\right)$}

This site is also on the abyssal floor east of Izu-Bonin Trench. The examined samples came from Cores 1 and 2; the former consists of Quaternary brown silty clay, and the latter comprises brown to reddish yellow zeolitic clay of Upper Cretaceous age.
The vertical mineral distributions at this site are listed in Table 3 and illustrated in Figure 3. In Core 1 illite and kaolinite are principal components. In Core 2, montmorillonite with one layer of water molecules between silica layers is found in addition to illite and kaolinite. It is worthy to note that concentrations of palygorskite occur in 


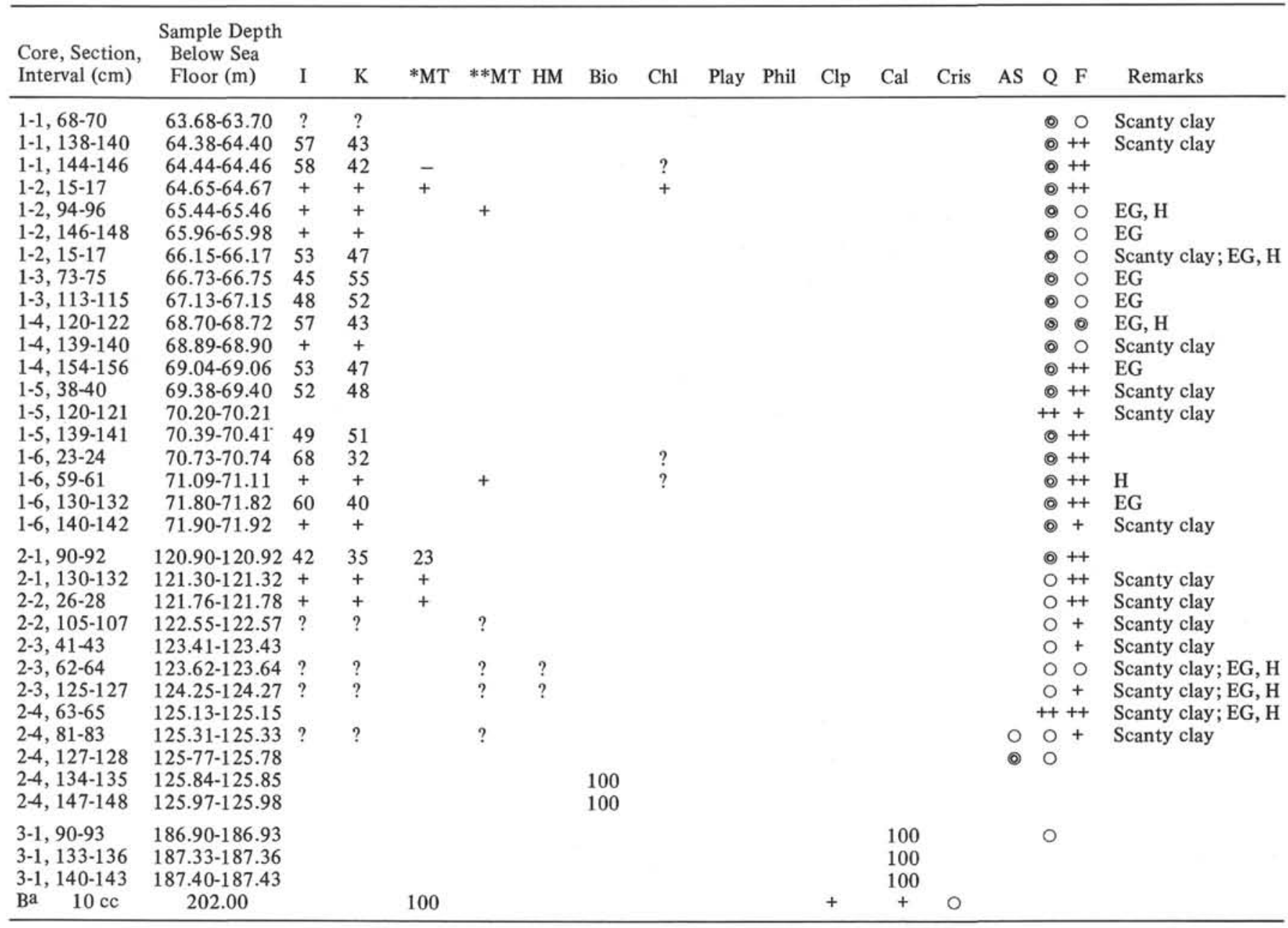

Note. See Table 1 for list of abbreviations and symbols. aSample from bit.

Core 2 while kaolinite is almost lacking. The $\mathrm{X}$-ray powder data of palygorskite are tabulated in Table 4. Another remarkable feature is that clinoptilolite is found in almost all the samples of Core 2 (Cretaceous sequence). Chlorite seems to be present in a few samples of Core 2.

Electron microprobe X-ray analysis was made on Sample 196-2-1, 145-147 cm, which is composed mainly of illite, montmorillonite, palygorskite, and clinoptilolite (Plates 3 and 4). The $\mathrm{Cl}$ image on Plate 4, Figure 1 suggests that water between silica layers of montmorillonite contains a significant amount of chlorine in solution.

\section{Site $198\left(25^{\circ} 49.54^{\prime} \mathrm{N}, 154^{\circ} 35.05^{\prime} \mathrm{E}\right)$}

This site is located north of Marcus Island. The analyzed specimens were sampled from the sediments recovered from Hole 198A. The whole sequence of the sediments in Hole 198A is of LateCretaceous age. The sediments of Cores 1 to 5 are composed of dark brown zeolitic silty clay, which is also rich in volcanic ash.

The abundance of minerals in the studied samples is given in Table 5 and Figure 4. In Cores 1,2, and 3 illite, kaolinite, and montmorillonite were commonly observed.
Quartz also occurs in significant amounts in almost all the samples, while feldspar is present only in trace amounts. Core 4 is characterized not only by the suite of montmorillonite and hydrous mica, but also by cristobalite. The latter is characteristic of the lower part of this core. An interesting trend recognized throughout the whole sequence is that chlorite is detected, though in trace amounts, in the upper sequence, whereas clinoptilolite appears in the lower sequence. An occurrence of clinoptilolite is displayed in Plate 5, Figure 1, and the X-ray powder data of this mineral from Core 4 are also shown in Table 6.

\section{Site $199\left(13^{\circ} 30.78^{\prime} \mathrm{N}, 156^{\circ} 10.34^{\prime} \mathrm{E}\right)$}

Site 199 was drilled at the east margin of the Caroline Abyssal Plain north of the Caroline Islands. The upper part of the sedimentary sequence at Site 199 is represented by turbidites which consist of brown zeolitic clay, ash, and radiolarian ooze. The age of this sequence, about 210 meters thick, ranges from middle Miocene to Quaternary. The lower sequence, about 170 meters thick, comprises interbedded chalk, limestone, chert, and tuff of Late Cretaceous to Paleocene age. 


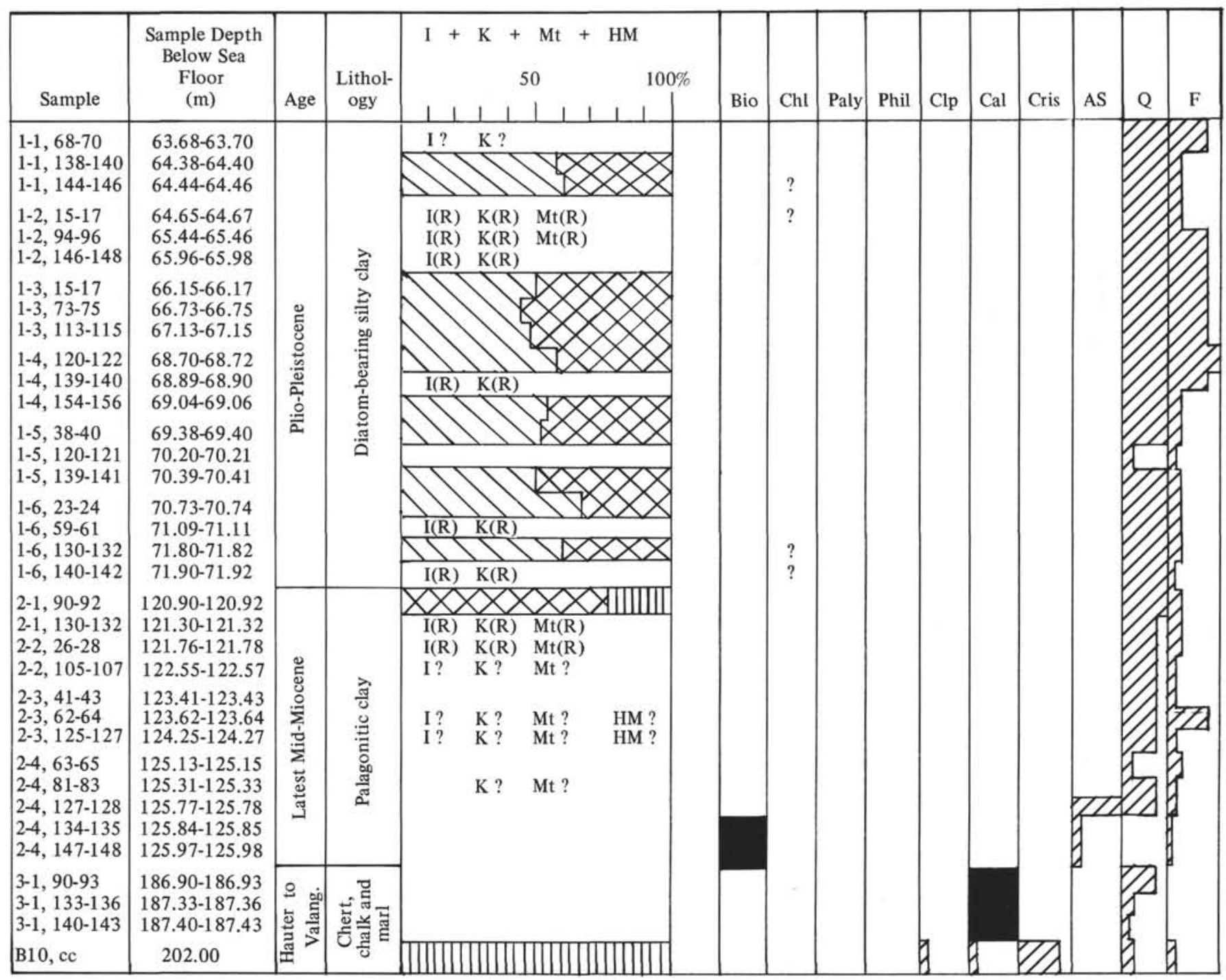

Figure 2. Variations in mineral composition of samples from Hole 195. (For symbols used, see Figure 1.)

Mineral compositions of the sediments at this site are shown in Table 7 and Figure 5. The principal clay mineral in the whole sediments is montmorillonite. A zeolite, either phillipsite or clinoptilolite, was detected almost consistently throughout the whole sequence except for Core 5 .

The suite of phillipsite and montmorillonite with one layer of water molecules is characteristic of the upper sequence (Cores 1 and 2), the suite of phillipsite and montmorillonite showing a broad reflection between $12 \AA$ and $15 \AA$ are of the middle sequence (Cores 3 and 4), and either the suite of phillipsite and montmorillonite with two layers of water molecules or single occurrence of montmorillonite of the last variety characterizes the lower sequence (Cores 5 and 6).

A remarkable tendency is also seen in the vertical distribution of zeolitic minerals; phillipsite is characteristic of Cores 1 through 6 (middle Miocene or younger ?), while clinoptilolite is characteristic of Cores 10 through 13 (Late Cretaceous to Paleocene).
Calcite was found in most of the samples from Cores 1 , 4,6 , and 10 . Hydrous mica and cristobalite are restricted to the lowest sequence (Cores 10-13). Quartz and feldspar are present almost consistently throughout the whole sequence. Illite was not detected at all throughout the sequence.

SEM image of a montmorillonite-rich sample (199-5-1, $55-57 \mathrm{~cm}$ ) is shown in Plate 5, Figure 2.

\section{CONCLUDING REMARKS}

The results of mineralogical analysis are schematically presented in Figures 1, 2, 3, 4, and 5. Characteristic mineral assemblages at each hole are also systematically arranged in Tables 8 and 9 .

These results show some unusual and characteristic features as follows: (1) Kaolinite is found in considerable amounts in most of the samples, except for the lower sequence at Sites 195, 198, and 199. (2) Chlorite was hardly detectable at all sites except at Site 199. (3) Illite is 
TABLE 3

Results of X-Ray Diffraction Analyses, Hole 196

\begin{tabular}{|c|c|c|c|c|c|c|c|c|c|c|c|c|c|c|c|c|c|}
\hline $\begin{array}{l}\text { Core, Section } \\
\text { Interval }(\mathrm{cm})\end{array}$ & $\begin{array}{l}\text { Sample Depth } \\
\text { Below Sea } \\
\text { Floor (m) }\end{array}$ & 1 & $\mathrm{~K}$ & $* \mathrm{MT}$ & $* * \mathrm{MT}$ & HM & Bio & Chl & Paly & Phil & Clp & $\mathrm{Cal}$ & Cris & AS & Q & $\mathrm{F}$ & Remarks \\
\hline $\begin{array}{l}1-1,140-142 \\
1, \mathrm{CC}, 10 \mathrm{cc}\end{array}$ & $\begin{array}{c}38.90-38.92 \\
47.00\end{array}$ & $\begin{array}{l}55 \\
58\end{array}$ & $\begin{array}{l}45 \\
42\end{array}$ & & & & & & & & & & & & $\begin{array}{l}0 \\
0\end{array}$ & $\begin{array}{l}++ \\
++\end{array}$ & $\begin{array}{l}\text { EG, H } \\
\text { EG, H }\end{array}$ \\
\hline $\begin{array}{l}2-1,4-6 \\
2-1,36-38 \\
2-1,90-92 \\
2-1,128-130 \\
2-1,145-147 \\
2-2,40-42 \\
2-2,105-107 \\
2-3,30-32\end{array}$ & $\begin{array}{l}104.04-104.06 \\
104.36-104.38 \\
104.90-104.92 \\
105.28-105.30 \\
105.45-105.47 \\
105.90-105.92 \\
106.55-106.57 \\
107.30-107.32\end{array}$ & $\begin{array}{l}\odot \\
52 \\
61 \\
+ \\
+\end{array}$ & $\begin{array}{r}++ \\
10 \\
9 \\
?\end{array}$ & $\begin{array}{l}0 \\
38 \\
30 \\
0 \\
0 \\
+ \\
+ \\
+\end{array}$ & & + & & & $\begin{array}{l}0 \\
0 \\
0 \\
0 \\
0\end{array}$ & & $\begin{array}{l}+ \\
+ \\
+ \\
0 \\
0 \\
+ \\
+ \\
0\end{array}$ & & & & $\begin{array}{l}0 \\
0 \\
0 \\
+ \\
0 \\
+ \\
0 \\
+\end{array}$ & $\begin{array}{l}+ \\
+ \\
- \\
+ \\
- \\
++\end{array}$ & $\begin{array}{l}\text { EG } \\
\text { EG } \\
\text { EG } \\
\text { EG } \\
\text { EG } \\
\text { EG } \\
\text { EG } \\
\text { EG, H }\end{array}$ \\
\hline $\begin{array}{l}2-3,36-37 \\
2-3,99-101 \\
2-4,13-15 \\
2-4,70-72 \\
2-4,115-117 \\
2-5,50-52 \\
2-5,102-104 \\
1-6,30-32 \\
1-6,113-115\end{array}$ & $\begin{array}{l}107.36-107.37 \\
107.99-108.01 \\
108.63-108.65 \\
109.20-109.22 \\
109.65-109.67 \\
110.50-110.52 \\
111.02-111.04 \\
111.80-111.82 \\
112.63-112.65\end{array}$ & $\begin{array}{l}? \\
? \\
+ \\
26 \\
14 \\
0\end{array}$ & $\begin{array}{c}? \\
++ \\
37 \\
24 \\
0\end{array}$ & $\begin{array}{l}+ \\
+ \\
+ \\
+ \\
+ \\
+ \\
37 \\
62 \\
0\end{array}$ & & & & $\begin{array}{l}? \\
?\end{array}$ & $\begin{array}{l}0 \\
0 \\
0 \\
0 \\
0 \\
0\end{array}$ & & $\begin{array}{l}+ \\
0 \\
+ \\
0 \\
+ \\
+ \\
+\end{array}$ & & & & $\begin{array}{l}+ \\
+ \\
+ \\
+ \\
0 \\
+ \\
0 \\
++ \\
0\end{array}$ & $\begin{array}{l}0 \\
0 \\
+ \\
0\end{array}$ & $\begin{array}{l}\text { EG } \\
\text { EG } \\
\text { EG } \\
\text { EG } \\
\text { EG } \\
\text { EG } \\
\text { EG } \\
\text { EG } \\
\text { EG, H }\end{array}$ \\
\hline
\end{tabular}

Note. See Table 1 for list of abbreviations and symbols.

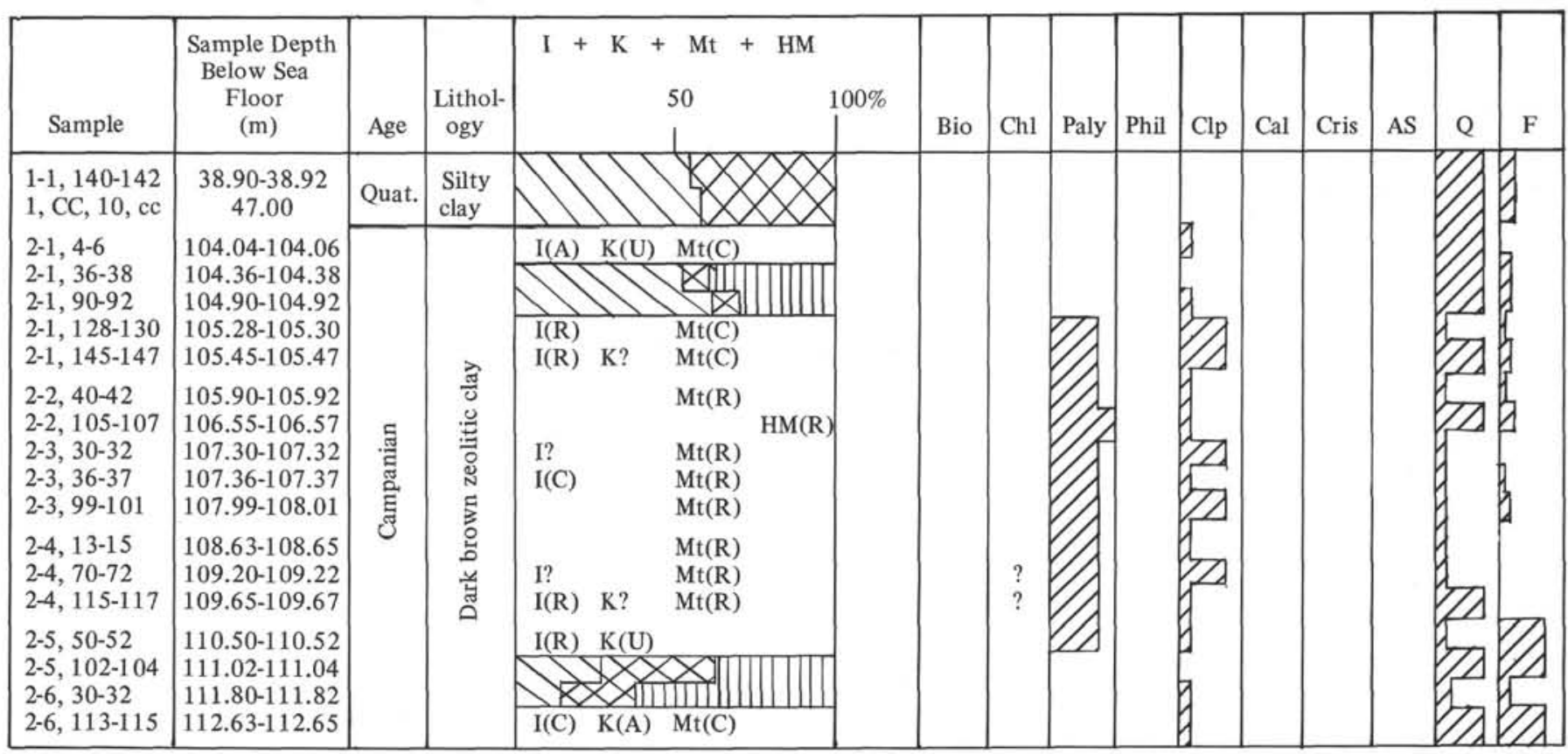

Figure 3. Variations in mineral composition of samples from Hole 196. (For symbols used, see Figure 1.)

not present at Site 199. (4) Very fresh biotite occurs locally. (5) Hydrous mica is concentrated in the lower sequences of some holes. (6) Three types of montmorillonite, namely, with one layer of water molecules, with two layers of water molecules, and with mixed layers of water molecules, are discriminated; the one-layer variety is characteristic of the upper sequence, while the two-layer variety is characteristic of the lower sequence. The mixed-layer type characterizes the transitional part between the upper and lower sequences. (7) Palygorskite is dominant in the middle part of Site 196. (8) Phillipsite was detected only in the Tertiary sequence of Site 199. (9) Clinoptilolite is usually found in lower sequences in most holes.

Much of the high concentrations of kaolinite, which mostly coexists with quartz and feldspar, might have been introduced as windborne land debris, and some might be the product of alteration of feldspars. The paucity or absence of chlorite is very difficult to interpret, though 
TABLE 4

X-ray Powder Diffraction Data for Palygorskite

\begin{tabular}{|c|c|c|c|c|}
\hline \multirow[b]{2}{*}{ hkl } & \multicolumn{2}{|c|}{$\begin{array}{c}\text { From Bradley } \\
(1940)\end{array}$} & \multicolumn{2}{|c|}{$\begin{array}{c}\text { DSDP } 196-2-2 \text {, } \\
105-107 \mathrm{~cm}\end{array}$} \\
\hline & $d(\AA)$ & $I$ & $d(\AA)$ & $I$ \\
\hline 110 & 10.50 & 10 & 10.5 & 100 \\
\hline 200 & 6.44 & 6 & 6.42 & 13 \\
\hline $\begin{array}{l}130 \\
220\end{array}$ & 5.42 & 5 & 5.43 & 5 \\
\hline 040 & 4.49 & 8 & 4.48 & 18 \\
\hline 310 & 4.18 & 3 & & \\
\hline 240 & 3.69 & 5 & 3.69 & 5 \\
\hline 330 & & & & \\
\hline 150 & 3.50 & 3 & & \\
\hline 400 & 3.23 & 10 & 3.22 & 44 \\
\hline 420 & 3.03 & 1 & & \\
\hline 350 & & & & \\
\hline 440 & 2.61 & 8 & 2.60 & 14 \\
\hline 510 & 2.55 & 3 & 2.54 & 7 \\
\hline 530 & 2.38 & 3 & & \\
\hline 080 & & & & \\
\hline 600 & 2.15 & 5 & & \\
\hline 550 & & & & \\
\hline $\begin{array}{l}480 \\
390\end{array}$ & & 1 & & \\
\hline $\begin{array}{l}390 \\
660\end{array}$ & 1.82 & & & \\
\hline 800 & 1.62 & 1 & & \\
\hline 680 & 1.56 & 3 & & \\
\hline $0,12,0^{\circ}$ & 1.50 & 5 & & \\
\hline
\end{tabular}

Heath (1969) has pointed out the scarcity of chlorite in the "oceanic" mineral association. Hydrous mica is an alteration product of biotite, because some features of biotite are still preserved in the X-ray diffraction pattern. The concentrations of fresh biotite, opaline silica, and hydrous mica suggest rather intense volcanic activities on the ocean bottom. Even small quantities of illite were not detected in the samples from Site 199, in which calcite was fairly commonly found. This is interpreted to indicate greater concentrations of $\mathrm{Ca}$ cations than $\mathrm{K}$ cations in the sediments.

Some minerals show vertical changes of relative amounts, as is indicated by a downward decrease of illite at Holes 195, 196, and 198A. As a general tendency, the suites of illite and kaolinite associated with or without montmorillonite having one layer of water molecules characterize the upper sequence of sedimentary sections, whereas the suite of clinoptilolite, montmorillonite with two layers of water molecules, and hydrous mica is characteristic of the lower sequence. Furthermore, as seen in Hole 199, phillipsite marks the upper sequence, while clinoptilolite characterizes the lower. That such vertical changes are due to burial diagenesis seems to be almost conclusive, judging from the zonal distribution of authigenic zeolites in Neogene pyroclastic sediments in Japan (e.g., Iijima and Utada, 1971), where clinoptilolite and montmorillonite represent the second stage of increasing

TABLE 5

Results of X-Ray Diffraction Analyses, Hole 198A

\begin{tabular}{|c|c|c|c|c|c|c|c|c|c|c|c|c|c|c|c|c|c|}
\hline $\begin{array}{l}\text { Core, Section, } \\
\text { Interval }(\mathrm{cm})\end{array}$ & $\begin{array}{l}\text { Sample Depth } \\
\text { Below Sea } \\
\text { Floor }(\mathrm{m})\end{array}$ & I & $\mathrm{K}$ & ${ }^{*} \mathrm{MT}$ & $* * \mathrm{MT}$ & $\mathrm{HM}$ & Bio & Chl & Paly & Phil & Clp & $\mathrm{Cal}$ & Cris & AS & Q & $\mathrm{F}$ & Remarks \\
\hline $1-2,30-32$ & $92.30-92.32$ & 29 & 36 & 35 & & & & - & & & & & & & + & - & EG \\
\hline $1-2,125-127$ & $93.25-93.27$ & 47 & 27 & 26 & & & & - & & & & & & & + & - & EG \\
\hline $1-3,24-25$ & $93.74-93.75$ & (c) & t+ & 0 & & & & - & & & & & & & 0 & - & $\mathrm{EG}, \mathrm{H}$ \\
\hline $1-3,27-29$ & $93.77-93.79$ & 44 & 31 & 25 & & & & - & & & & & & & 0 & - & EG \\
\hline $1-3,125-127$ & $94.75-94.77$ & 40 & 28 & 32 & & & & - & & & & & & & 0 & - & EG \\
\hline $1-4,145-147$ & $96.45-96.47$ & 58 & 27 & 15 & & & & - & & & & & & & 0 & - & $\mathrm{EG}, \mathrm{H}$ \\
\hline $1-5,30-32$ & $96.80-96.82$ & 59 & 27 & 14 & & & & - & & & & & & & o & - & EG \\
\hline $1-5,125-127$ & $97.75-97.77$ & 32 & 14 & 54 & & & & - & & & & & & & + & - & EG \\
\hline $1-6,25-27$ & $98.25-98.27$ & 31 & 21 & 48 & & & & - & & & & & & & 0 & - & EG \\
\hline $1-6,125-127$ & $99.25-99.27$ & 28 & 31 & 41 & & & & & & & & & & & 0 & - & EG \\
\hline $2-1,110-112$ & $101.10-101.12$ & 60 & 21 & 19 & & & & & & & & & & & 0 & - & EG \\
\hline $2-2,58-60$ & $102.08-102.10$ & 57 & 17 & 26 & & & & & & & & & & & 0 & - & EG, \\
\hline $2-2,115-117$ & $102.65-102.67$ & 55 & 28 & 17 & & & & - & & & & & & & 0 & - & $\mathrm{EG}, \mathrm{H}$ \\
\hline $3-1,100-102$ & $110.50-110.52$ & + & ++ & (c) & & & & - & & & & & & & 0 & - & $\mathrm{EG}, \mathrm{H}$ \\
\hline $3-2,80-82$ & $111.80-111.82$ & 42 & 19 & 39 & & & & & & & & & & & 0 & - & EG \\
\hline $3-3,88-90$ & $113.38-113.40$ & 32 & 19 & 49 & & & & & & & + & & & & 0 & - & EG \\
\hline $3-3,99-100$ & $113.49-113.50$ & + & ++ & - & & & & & & & + & & & & 0 & - & EG \\
\hline $3-4,48-50$ & $114.48-114.50$ & 31 & 14 & 55 & & & & & & & + & & & & 0 & - & EG \\
\hline $3-4,138-140$ & $115.38-115.40$ & 37 & 13 & 50 & & & & - & & & + & & & & 0 & - & EG \\
\hline $3-5,32-35$ & $115.82-115.85$ & 42 & 12 & 46 & & & & & & & + & & & & + & - & EG \\
\hline $3-5,130-132$ & $116.80-116.82$ & 53 & 13 & 34 & & & & & & & + & & & & + & - & EG \\
\hline $3-6,50-52$ & $117.50-117.52$ & 54 & 8 & 38 & & & & & & & + & & & & + & - & EG \\
\hline $3-6,141-143$ & $118.41-118.43$ & 0 & ++ & 0 & & & & & & & 0 & & & & 0 & & EG \\
\hline $4-2,43-45$ & $120.93-120.95$ & & & 20 & & 80 & & & & & + & & & & 0 & & EG \\
\hline $4-2,125-127$ & $121.75-121.77$ & & & & 35 & 65 & & & & & + & & & & 0 & +t & EG \\
\hline $4-3,138-140$ & $123.38-123.40$ & & & & 59 & 41 & & & & & & & & & & & EG \\
\hline $4-4,21-23$ & $123.71-123.73$ & & & & + & + & & & & & (-) & & & & & & $\mathrm{EG}, \mathrm{H}$ \\
\hline $4-4,38-40$ & $123.88-123.90$ & & & & 46 & 54 & & & & & ++ & & & & 0 & + & EG \\
\hline $4-4,41-43$ & $123.91-123.93$ & & & & & 100 & & & & & & & 0 & & 0 & + & EG \\
\hline $4-4,112-114$ & $124.62-124.64$ & & & & 30 & 70 & & & & & ++ & & & & 0 & + & \\
\hline $4-4,121-124$ & $124.71-124.74$ & & & & & & & & & & & & ○ & & ( & & \\
\hline $4-5,12-14$ & $125.12-125.14$ & & & & & & & & & & & & - & & ( & & \\
\hline $4-5,43-45$ & $125.43-125.45$ & & & & 41 & 59 & & & & & (2) & & & & 0 & & \\
\hline $4-5,97-99$ & $125.97-125.99$ & & & & & & & & & & & & 0 & & ( & & EG \\
\hline
\end{tabular}

Note. See Table 1 for list of abbreviations and symbols. 


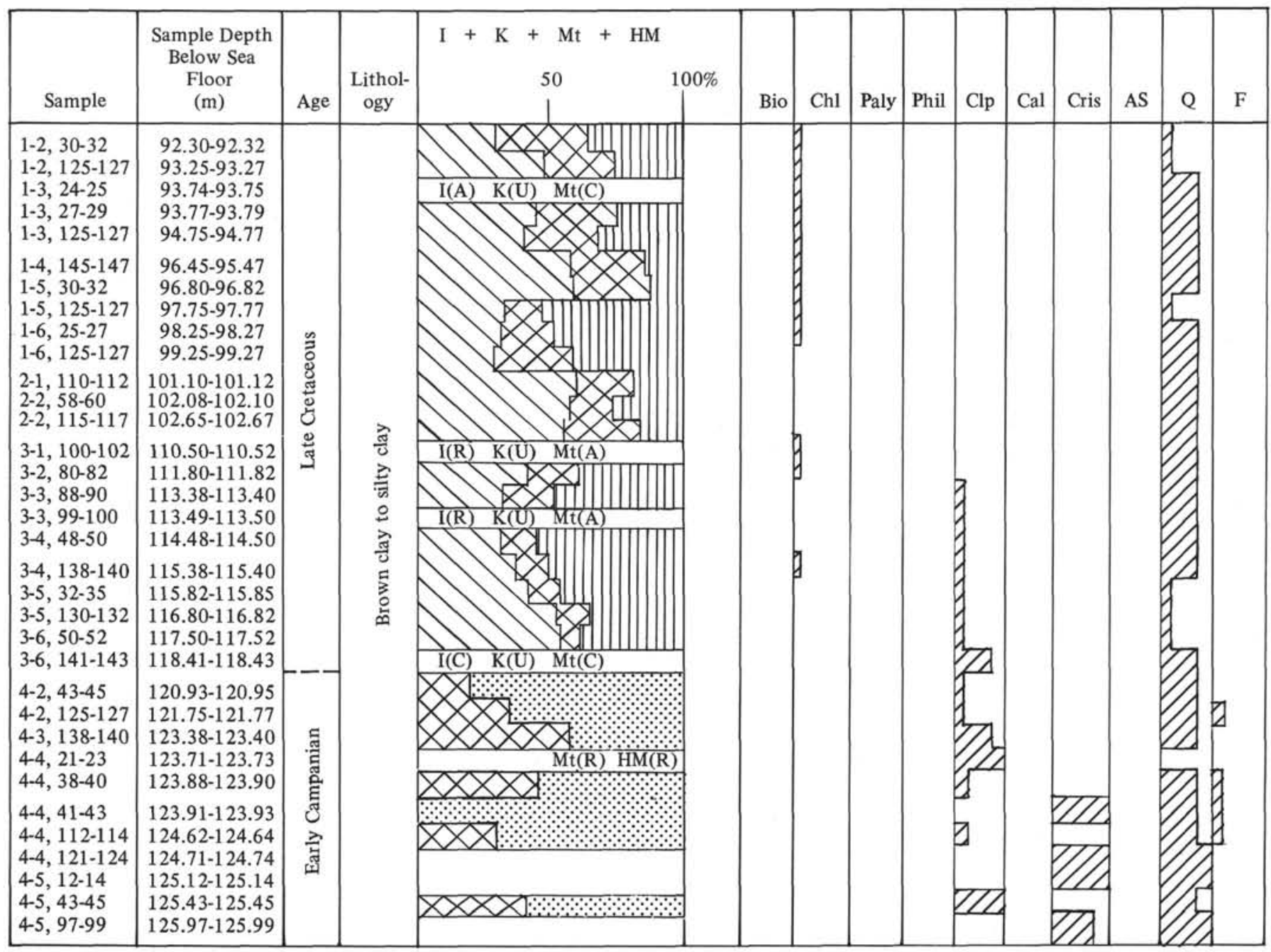

Figure 4. Variations in mineral composition of samples from Hole 198A. (For symbols used, see Figure 1.)

burial diagenesis from Stages I to V, namely; I: fresh glass, II: clinoptilolite, III: mordenite, IV: analcime, and V: albite zones. Especially, clinoptilolite is most abundant in sediments that contain little quartz (Figures 3 and 4). It also shows a negative correlation with cristobalite (Figure 4). This may result from conversion of cristobalite to quartz.

As regards palygorskite, Heezen et al. (1965) probably for the first time reported the occurrence of this mineral (or attapulgite) in deep-sea sediments. They found it in sediments at depths between 1000 and 2500 meters below sea level in the North Indian Ocean (Aden Gulf) and the Red Sea. Following Bonnati and Joensuu's (1968) finding of palygorskite from abyssal deposits in the Puerto Rico Trench, Cook et al. (1971) also detected it in deep-sea sediments sampled at the Ontong Java Plateau east of the Caroline Basin during DSDP Leg 7 in the northwestern Pacific.

Concerning the origin of palygorskite, Bonnati and Joensuu (1968) suggested that it could have been produced by hydrothermal reaction on the ocean floor. Stephen (1954) also reported the formation of palygorskite by hydrothermal action directly on igneous rocks. On the other hand, palygorskite is also reported to form either in fresh-water or lagoonal sediments (Kerr, 1937) or in shallow marine environments as a result of the action $\mathrm{Mg}$-rich solution on terrigenous clays (Müller, 1961).

Hathaway and Sachs (1965) interpreted that silica derived from the devitrification of silicic volcanic ash could have reacted with $\mathrm{Mg}$ in solution to form sepiolite, leaving clinoptilolite, quartz, and montmorillonite as residual products. It is known from laboratory experiments that reactions of silicate glasses with solutions at $\mathrm{pH}$ similar to that of seawater produce smectites only if magnesium is present in the solution (Hawkins and Roy, 1963). The $\mathrm{MgO} / \mathrm{SiO}_{2}$ ratio in palygorskite is between 2 and 3 times higher than in common smectite (excluding saponite). The concentration of magnesium in sea water is about $1.3 \mathrm{~g} / \mathrm{Kg}$, which is not enough to form palygorskite from acidic volcanic glasses on the ocean floor. 
TABLE 6

X-ray Powder Diffraction Data for Clinoptilolite

\begin{tabular}{|c|c|c|c|}
\hline \multicolumn{2}{|c|}{$\begin{array}{c}\text { From Mumpton } \\
(1960)\end{array}$} & \multicolumn{2}{|c|}{$\begin{array}{c}\text { DSDP } 198 \mathrm{~A}-4-5, \\
43-45 \mathrm{~cm}\end{array}$} \\
\hline$d(\AA)$ & $I$ & $d(\AA)$ & $I$ \\
\hline 9.00 & 10 & 9.0 & 77 \\
\hline 7.94 & 4 & 7.97 & 78 \\
\hline 6.77 & 3 & & \\
\hline 6.64 & 2 & & \\
\hline 5.91 & 1 & & \\
\hline 5.24 & 3 & & \\
\hline 5.11 & 1 & & \\
\hline 4.69 & 2 & & \\
\hline 4.48 & 2 & 4.46 & 17 \\
\hline 4.34 & 2 & & \\
\hline 3.96 & 10 & 3.97 & 100 \\
\hline 3.90 & 8 & 3.91 & 35 \\
\hline 3.83 & 1 & & \\
\hline 3.73 & 1 & & \\
\hline 3.55 & 2 & 3.55 & 7 \\
\hline 3.46 & 2 & 3.47 & 14 \\
\hline 3.42 & 6 & & \\
\hline 3.12 & 3 & & \\
\hline 3.07 & 2 & & \\
\hline 3.04 & 2 & 3.03 & 21 \\
\hline 2.97 & 5 & 2.98 & 33 \\
\hline 2.87 & 1 & & \\
\hline 2.82 & 3 & 2.81 & 39 \\
\hline
\end{tabular}

It is probable that the deep-sea palygorskite in the present case is a result of alteration of magnesium-rich minerals.

Another interesting fact is that crystallinity of cristobalite and quartz content increase downwards in the lower sequence of Hole 198A, as shown in Figure 7. An X-ray diffraction curve of opaline silica is illustrated for comparison in Figure 6. It is suggested that burial diagenesis affects the increase of crystallinity of cristobalite and quartz content. Therefore, it is concluded that not all the quartz is of allochthonous terrigenous origin.

\section{ACKNOWLEDGMENTS}

We thank Drs. H. E. Cook and Ivar Zemmels (University of California, Riverside) for their helpful suggestions for the
X-ray analyses data and Mr. Tadao Wakabayashi (Shimadzu Seisakusho Ltd., Kyoto) for his help in electron microprobe $\mathrm{X}$-ray analysis.

\section{REFERENCES}

Bonnati, E. and Joensuu, O., 1968. Palygorskite from the deep sea: Am. Minerol., v. 53, p. 975.

Bradley, M. F., 1940. Structural scheme of attapulgite: Am. Minerol., v. 25, p. 405.

Cook, H. E., Rex, R. W., Eklund, W. A., and Murray, B., 1971. X-ray mineralogy studies, Leg 7. In Winterer et al., Initial Reports of the Deep Sea Drilling Project, Volume VII: Washington (U. S. Government Printing Office), p. 913.

Hathaway, J. C. and Sachs, P. L., 1965. Sepiolite and clinoptilolite from the Middle Atlantic Ridge: Am. Minerol., v. 50, p. 852.

Hawkins, D. B. and Roy, R., 1963. Experimental hydrothermal studies on rock alteration and clay mineral formation: Geochim. Cosmochim. Acta, v. 27, p. 1047.

Heath, G. R., 1969. Mineralogy of Cenozoic deep-sea sediments from the equatorial Pacific Ocean: Geol. Soc. Am. Bull., v. 80, p. 1997.

Heezen, B. C., Nesteroff, W. D., Oberlin, A., and Sabatier, G., 1965. Découverte d' attapulgite dans les sédiments profonds du golfe d'Aden et de la Mer Rouge: Compt. Rend. Acad. Sci. Paris, v. 260 , p. 5819.

Iijima, A. and Utada, M., 1971. Present-day zeolitic diagenesis of the Neogene geosynclinal deposits in the Niigata Oil Field, Japan. In Advances in Chemistry Series No. 101 "Molecular Sieve Zeolites-I", Washington (Am. Chem. Soc.), p. 342.

Kerr, P. F., 1937. Attapulgus clay: Am. Mineral., v. 22, p. 534.

Müller, G., 1961. Palygorskit und Sepiolith in teriären und quartären Sedimenten von Hadramaut (S. Arabien): Neues Jahrb. Mineral. Abh., v. 97, p. 275.

Mumpton, F. A., 1960. Clinoptilolite redefined: Am. Mineral., v. 45 , p. 351.

Oinuma, K. and Kobayashi, K., 1961. Problems of rapid clay mineralogical analysis of sedimentary rocks: Clay Sci., v. 1, p. 8.

Stephen, I., 1954. An occurrence of palygorskite in the Shetland Isles: Mineral. Mag., v. 30, p. 471.

Wada, K., 1961. Lattice expansion of kaolin minerals by treatment with potassium acetate. Am. Minerol., v. 46, p. 78 . 
TABLE 7

Results of X-Ray Diffraction Analyses, Hole 199

\begin{tabular}{|c|c|c|c|c|c|c|c|c|c|c|c|c|c|c|c|c|c|}
\hline $\begin{array}{l}\text { Core, Section, } \\
\text { Interval }(\mathrm{cm})\end{array}$ & $\begin{array}{l}\text { Sample Depth } \\
\text { Below Sea } \\
\text { Floor (m) }\end{array}$ & I & $\mathrm{K}$ & ${ }^{*} \mathrm{Mt}$ & $* * \mathrm{Mt}$ & $\mathrm{HM}$ & Bio & $\mathrm{Chl}$ & Paly & Phil & Clp & $\mathrm{Cal}$ & Cris & AS & Q & F & Remarks \\
\hline $1-1,145-147$ & $58.89-58.97$ & & & & & & & & & & & 0 & & & + & + & \\
\hline $1-2,18-20$ & $59.18-59.20$ & & & & & & & & & & & (-) & & & + & + & \\
\hline $1-2,90-92$ & $59.90-59.92$ & & + & & & & & & & & & (c) & & & - & + & \\
\hline $1-3,18-20$ & $60.68-60.70$ & & + & + & & & & & & & & (2) & & & + & + & \\
\hline $1-3,105-107$ & $61.55-61.57$ & & $?$ & 0 & & & & & & $?$ & & & & & + & ++ & $\mathrm{Eg}, \mathrm{H}$ \\
\hline $1-4,54-56$ & $62.54-62.56$ & & & 0 & & & & & & + & & & & & + & ++ & Scanty clay; EG \\
\hline $1-4,105-107$ & $63.05-63.07$ & & & & & & & & & & & (-) & & & & & \\
\hline $1-5,2-4$ & $63.52-63.54$ & & ? & ? & & & & & & ? & & (2) & & & + & ++ & EG \\
\hline $1-5,100-102$ & $64.50-64.52$ & & & 0 & & & & & & + & - & & & & + & ++ & EG \\
\hline $2-1,92-94$ & $67.92-67.94$ & & & 0 & & & & & & 0 & & & & & + & ++ & EG, H \\
\hline $2-1,110-112$ & $68.10-68.12$ & & & + & & & & & & 0 & & & & & + & ++ & Scanty clay; H \\
\hline $2-2,38-40$ & $68.88-68.90$ & & ? & 0 & & & & & & + & & & & & + & ++ & $\mathrm{EG}, \mathrm{H}$ \\
\hline $2-3,140-142$ & $71.40-71.42$ & & + & + & & & & & & & & & & & & + & Scanty clay; EG \\
\hline $2-4,20-22$ & $71.70-71.72$ & & ? & + & & & & & & ? & & & & & & + & Scanty clay \\
\hline $2-4,131-133$ & $72.81-72.83$ & & ? & + & & & & & & + & & & & & + & ++ & $\mathrm{EG}, \mathrm{H}$ \\
\hline $2-5,40-42$ & $73.40-73.42$ & & ? & $(+)$ & & & & & & + & & & & & & ++ & EG, H \\
\hline $2-5,117-119$ & $74.17-74.19$ & & ? & $(+)$ & & & & & & + & & 0 & & & - & + & \\
\hline $2-6,100-102$ & $75.50-75.52$ & & & $(+)$ & & & & & & + & & + & & & & + & \\
\hline $3-1,30-32$ & $76.80-76.82$ & & ? & $(+)$ & & & & & & ? & & & & & + & ++ & \\
\hline $3-2,58-60$ & $78.58-78.60$ & & ? & $(+)$ & & & & & & + & & & & & + & ++ & \\
\hline $3-2,98-100$ & $78.98-79.00$ & & & $(+)$ & & & & & & + & & & & & + & ++ & EG \\
\hline $3-3,100-102$ & $80.50-80.52$ & & & $(+)$ & & & & & & + & & & & & + & ++ & EG, H \\
\hline $3-4,68-70$ & $81.68-81.70$ & & ? & $(+)$ & & & & & & + & & & & & + & ++ & \\
\hline $3-5,94-96$ & $83.44-83.46$ & & & & & & & & & + & & & & & - & o & \\
\hline $4-1,70-72$ & $86.70-86.72$ & & ? & (O) & & & & & & 0 & & & & & + & ++ & EG, H \\
\hline $4-2,130-132$ & $88.80-88.82$ & & ? & (O) & & & & & & 0 & & & & & & 0 & \\
\hline $4-3,130-132$ & $90.30-90.32$ & & & (0) & & & & & & + & & + & & & & ++ & \\
\hline $4-4,110-112$ & $91.60-91.62$ & & ? & (O) & & & & & & + & & + & & & & ++ & \\
\hline $4-5,38-40$ & $92.38-92.40$ & & & (O) & & & & & & + & & (c) & & & & + & \\
\hline $4-5,128-130$ & $93.28-93.30$ & & & (O) & & & & & & + & & 0 & & & & ++ & \\
\hline $5-1,55-57$ & $143.55-143.57$ & & & & 100 & & & & & & & & & & + & + & EG \\
\hline $5-2,80-82$ & $145.30-145.32$ & & 56 & & 44 & & & & & & & & & & + & 0 & EG \\
\hline $5-3,140-142$ & $147.40-147.42$ & & & & 100 & & & & & & & & & & & + & EG, H \\
\hline $5-4,130-132$ & $148.80-148.82$ & & & & 100 & & & & & & & & & & & + & EG \\
\hline $5-5,100-102$ & $150.00-150.02$ & & & & 100 & & & & & & & & & & - & + & \\
\hline $5-6,44-45$ & $150.94-150.95$ & & & & 100 & & & & & & & & & & - & - & EG \\
\hline $5-6,110-112$ & $151.60-151.62$ & & & & 100 & & & & & & & & & & & - & \\
\hline $6-1,77-79$ & $200.77-200.79$ & & & & + & & & & & 0 & & & & & + & 0 & EG, H \\
\hline $6-1,120-122$ & $201.20-201.22$ & & & $(+)$ & & & & & & + & & + & & & & + & EG, H \\
\hline $6-2,25-27$ & $201.75-201.77$ & & & $(+)$ & & & & & & 0 & & + & & & & + & \\
\hline $6-2,60-62$ & $202.10-202.12$ & & & $(+)$ & & & & & & 0 & & + & & & & + & \\
\hline $6-2,130-132$ & $202.80-202.82$ & & & & 0 & & & & & + & & ++ & & & + & ++ & \\
\hline $6-3,109-111$ & $204.09-204.11$ & & $\because$, & & 0 & & & & & + & & - & & & & ++ & \\
\hline $6-4,38-40$ & $204.88-204.90$ & & & & 0 & & & & & + & & + & & & & ++ & \\
\hline $6-5.59-61$ & $206.59-206.61$ & & & & 0 & & & & & 0 & & & & & + & ++ & $\mathrm{H}$ \\
\hline $10-2,26-28$ & $372.76-372.78$ & & & & & & & & & & & 100 & & & & ++ & $\mathrm{EG}, \mathrm{H}$ \\
\hline $10-2,40-42$ & $372.90-372.92$ & & & & & & & & & & + & & 0 & & + & & \\
\hline $10-2,46-47$ & $372.96-372.97$ & & & $(+)$ & & & & & & & ++ & & & & + & - & $\mathrm{H}$ \\
\hline $10-2,64-66$ & $373.14-373.16$ & & & & & & & & & & & 100 & & & & & \\
\hline $10-2,144-145$ & $373-94-373.95$ & & & & & & & & & & & 100 & & & & & Scanty clay \\
\hline $11-2,105-106$ & $402-05-402.06$ & & & (71) & & 29 & & & & & ++ & & & & +t & + & \\
\hline $12-1,65-66$ & $438.15-438.16$ & & & (60) & & 40 & & & & & ++ & & 0 & & ++ & + & \\
\hline $13, \mathrm{CC}, 10 \mathrm{cc}$ & 456.50 & & & & & & & & & & ++ & ++ & 0 & & & + & Scanty clay \\
\hline
\end{tabular}

Note. See Table 1 for list of abbreviations and symbols. 


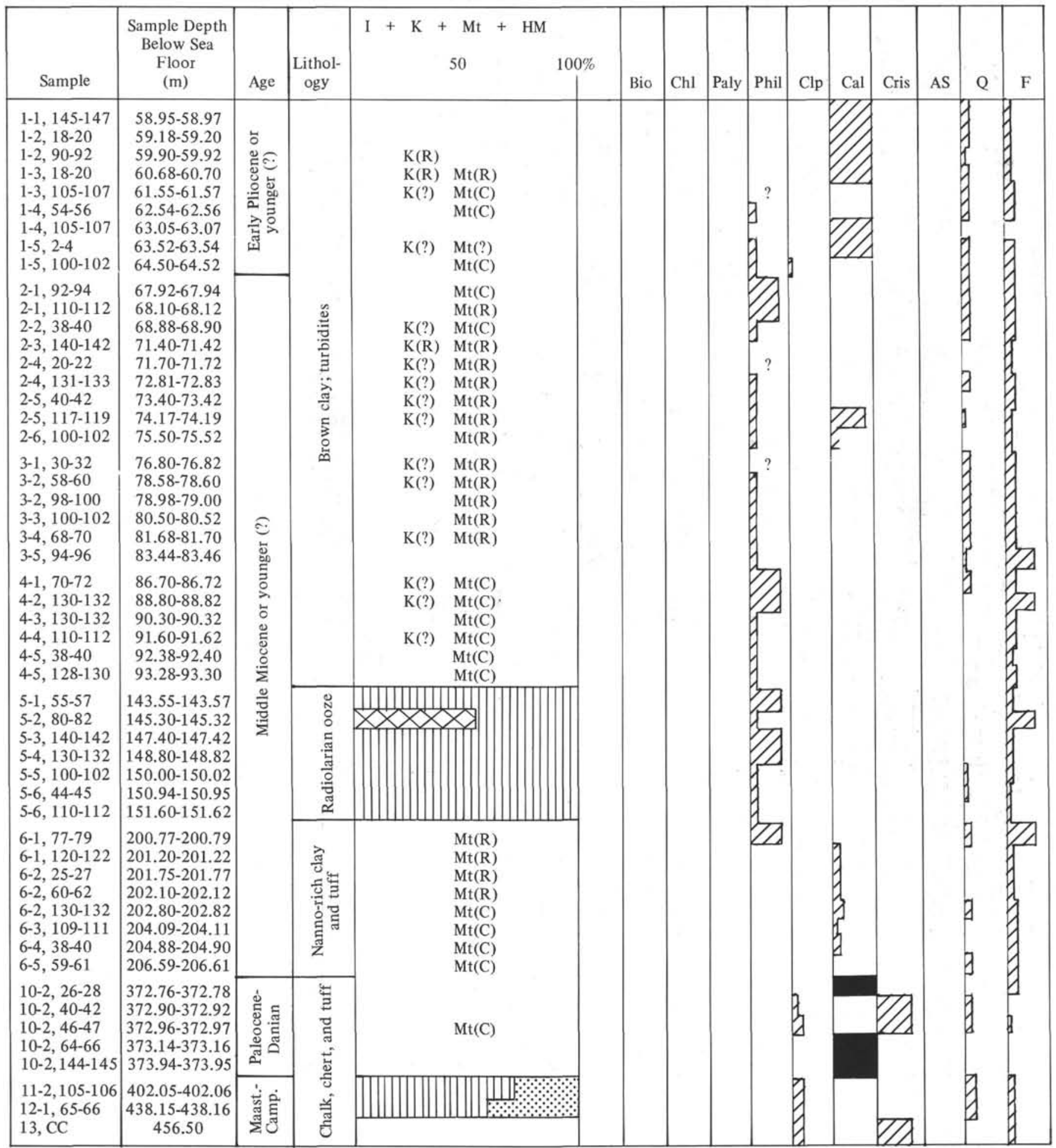

Figure 5. Variations in mineral composition of samples from Hole 199. (For symbols used, see Figure 1.) 
TABLE 8

Diagnostic Mineral Suites at Each Hole

\begin{tabular}{l|llllllll}
\hline Hole & \multicolumn{7}{|c}{ Mineral Suite } \\
\hline 194 & I & K & & & & & & \\
195 & I & K & Mt & & & Paly & Clp & \\
196 & I & K & Mt & & & [Clp] & \\
$198 \mathrm{~A}$ & I & K & Mt & Chl & [HM] & & [Clp] & Phil \\
199 & & & Mt & & & & \\
\hline
\end{tabular}

Note: [ ] Not consistent occurrence. For other symbols, see Table 1.

TABLE 9

Vertical Distribution of Clay Minerals

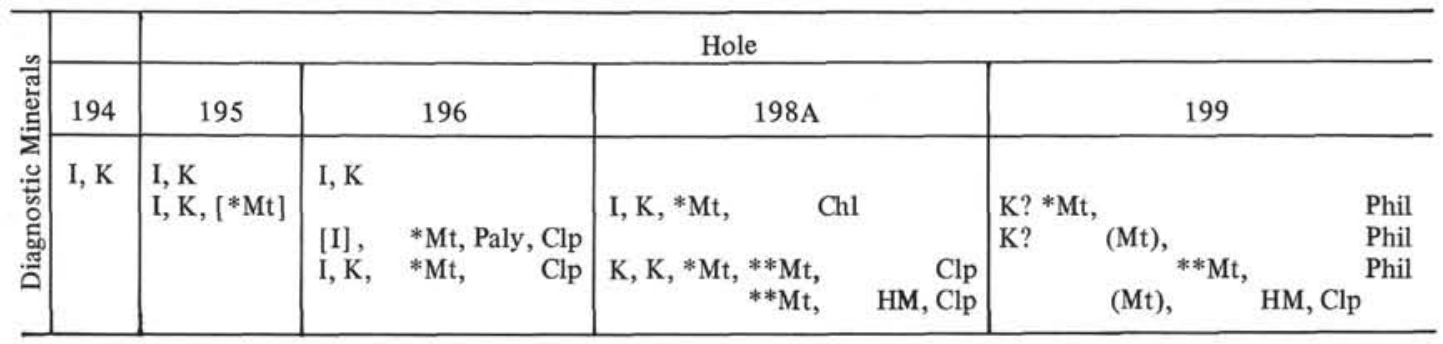

Note: For the symbols used, see Table 1.

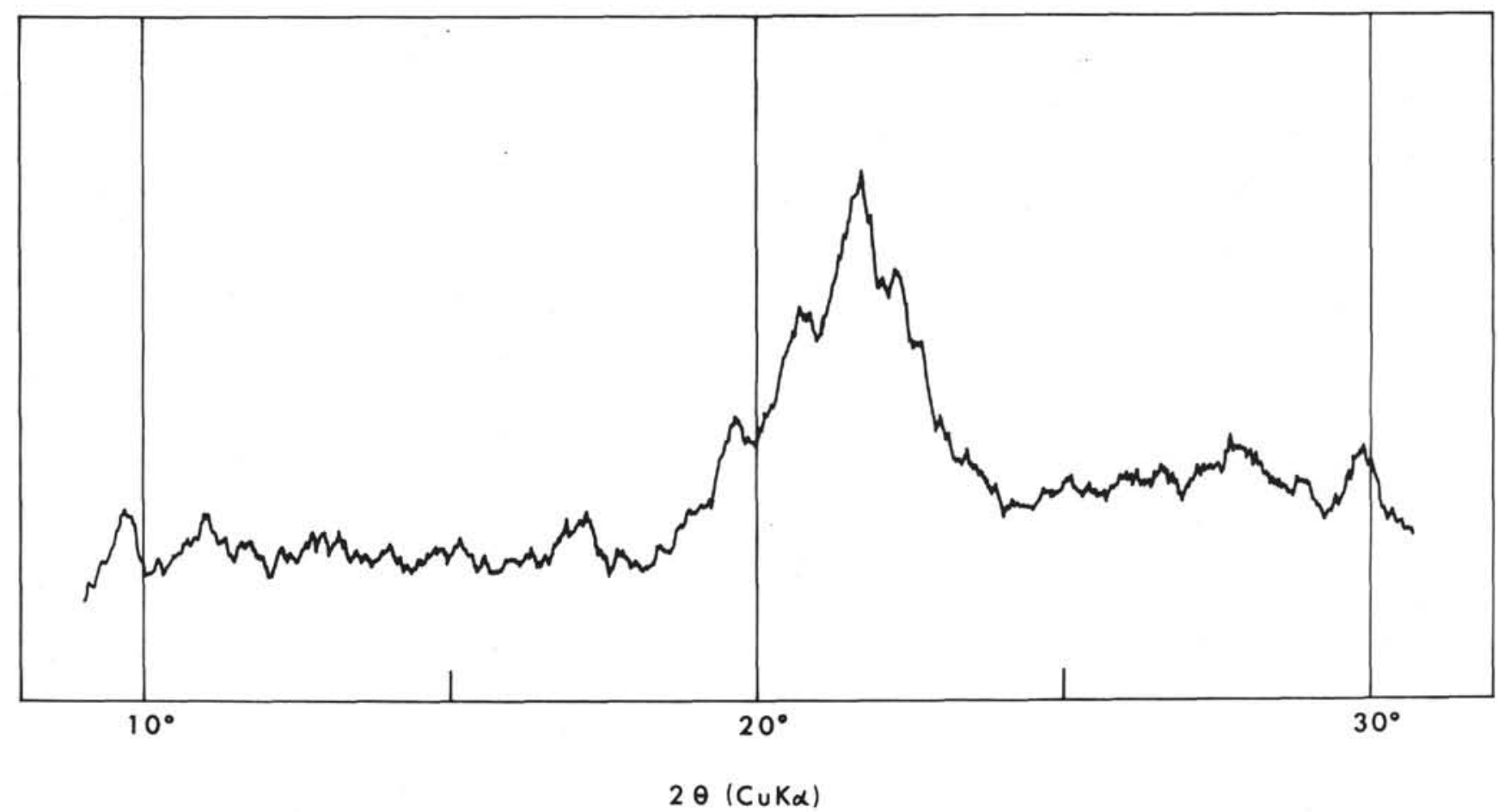

Figure 6. X-ray spectrogram indicating a low grade of crystallinity of opaline silica. Sample 199-13, CC. 


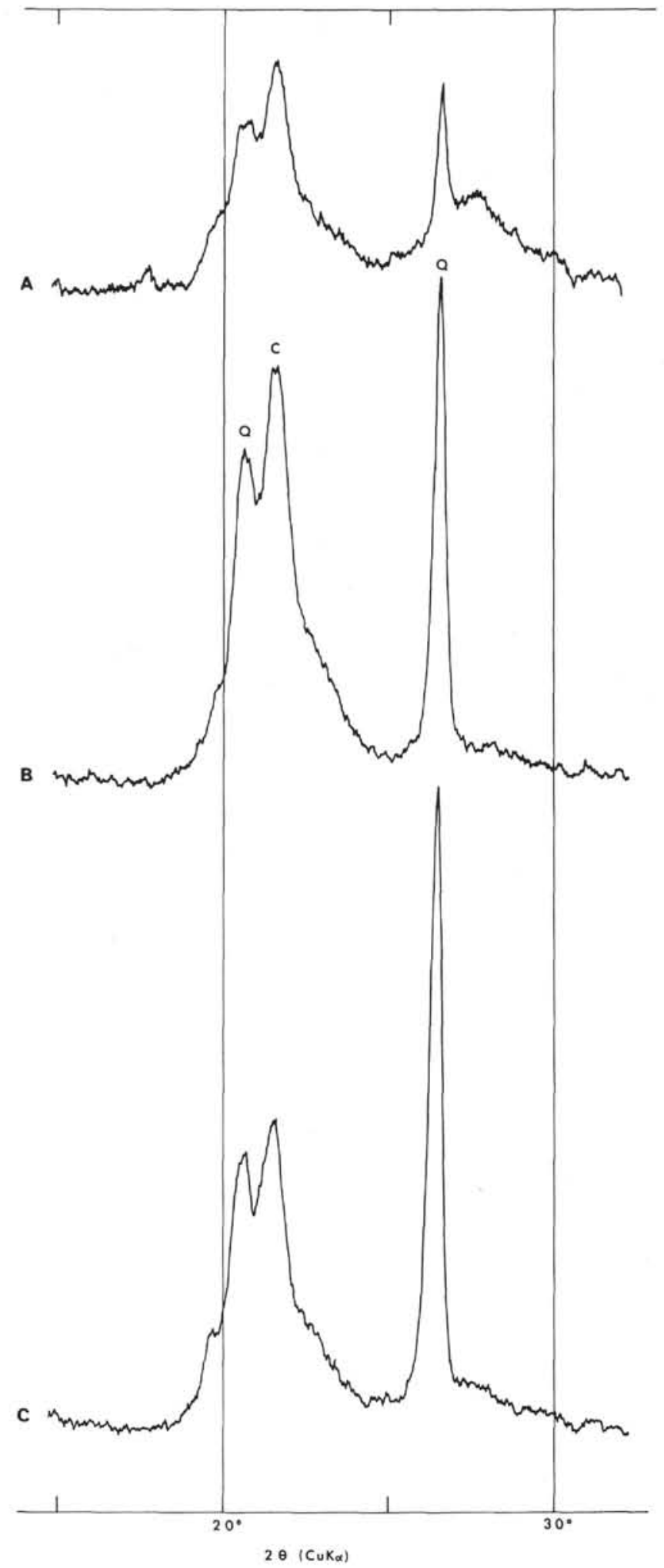

Figure 7. Diffractometer traces showing increasing crystallinity and content of cristobalite (C) and quartz (Q) with depth. (A) Sample 198A-4-4, 41-43 cm; (B) Sample 198A-4-4, 121-124 cm; (C) Sample 198A-4-5, $97-$ $99 \mathrm{~cm}$. 


\section{PLATE 1}

SEM and EPMA Images of Sample 195-1-6, 23-24 cm.

Length of Bar: $5 \mu$

\section{Figure $1 \quad$ SEM image.}

Figure $2 \quad \mathrm{Fe}$ image.

Figure $3 \quad$ Mn image.

Figure $4 \quad$ Ca image.

Figure $5 \quad \mathrm{~K}$ image. 


\section{PLATE 1}

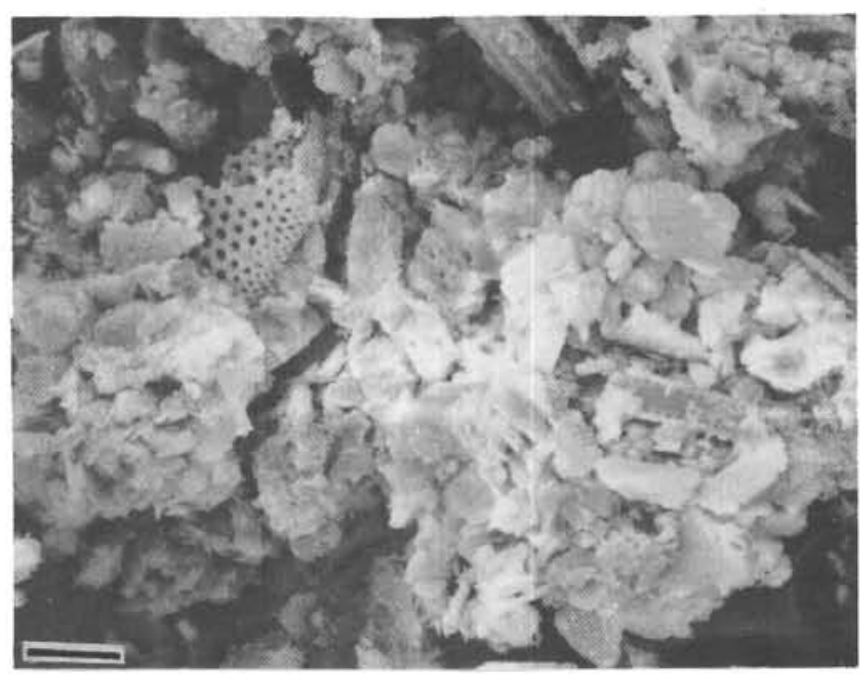

A

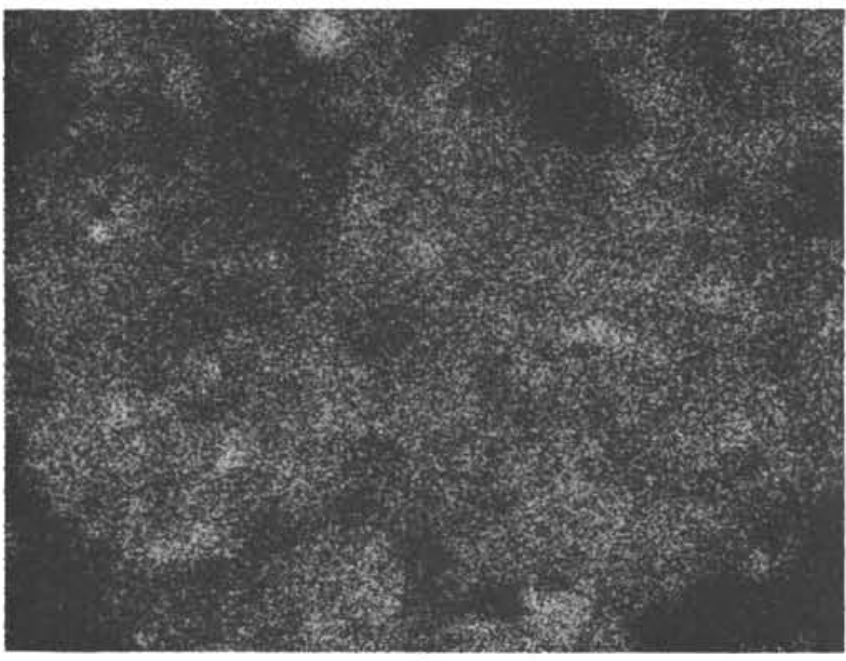

B

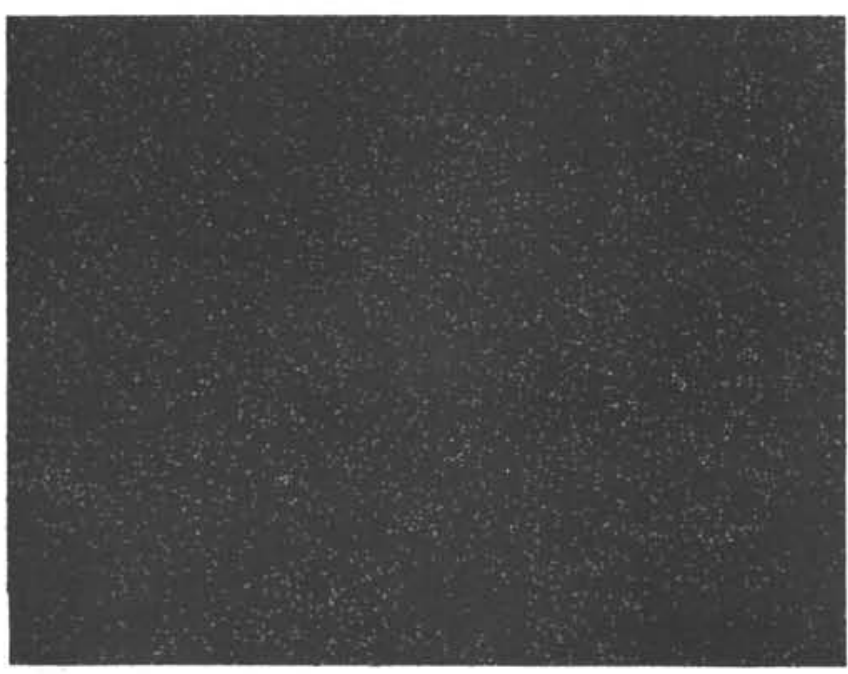

C

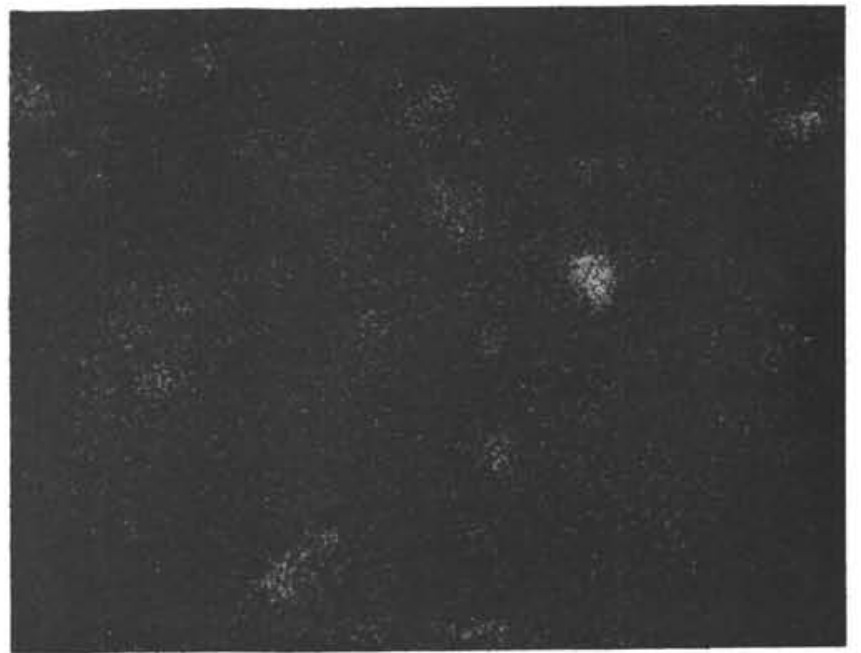

D

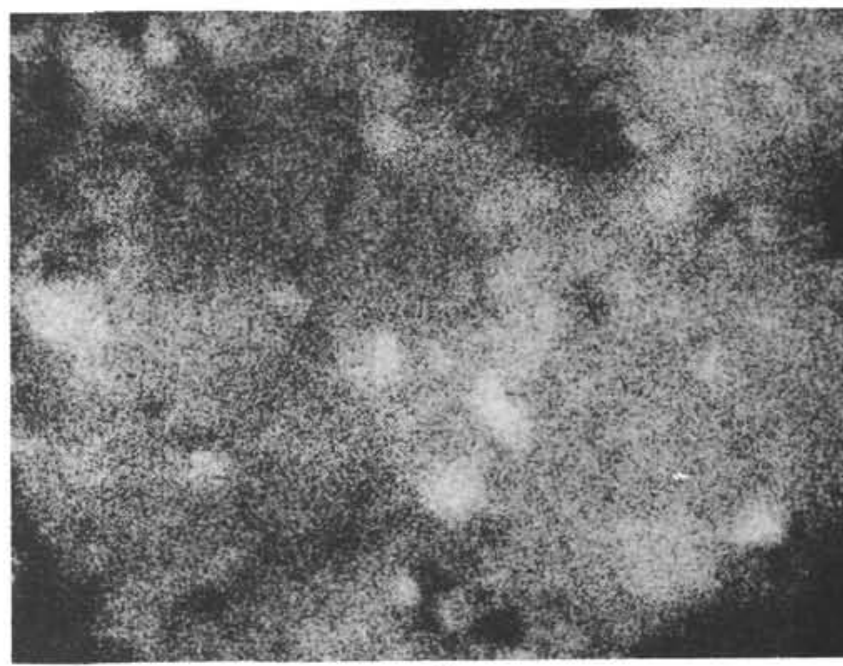

E 


\section{PLATE 2}

EPMA Images of Sample 195-1-6, 23-24 cm.

Same magnification as in Plate 1, Figure 1.

Figure $1 \quad \mathrm{Cl}$ image.

Figure $2 \quad$ Mg image.

Figure $3 \quad$ Na image.

Figure $4 \quad \mathrm{Al}$ image.

Figure $5 \quad$ Si image.

Figure $6 \quad 0$ image. 

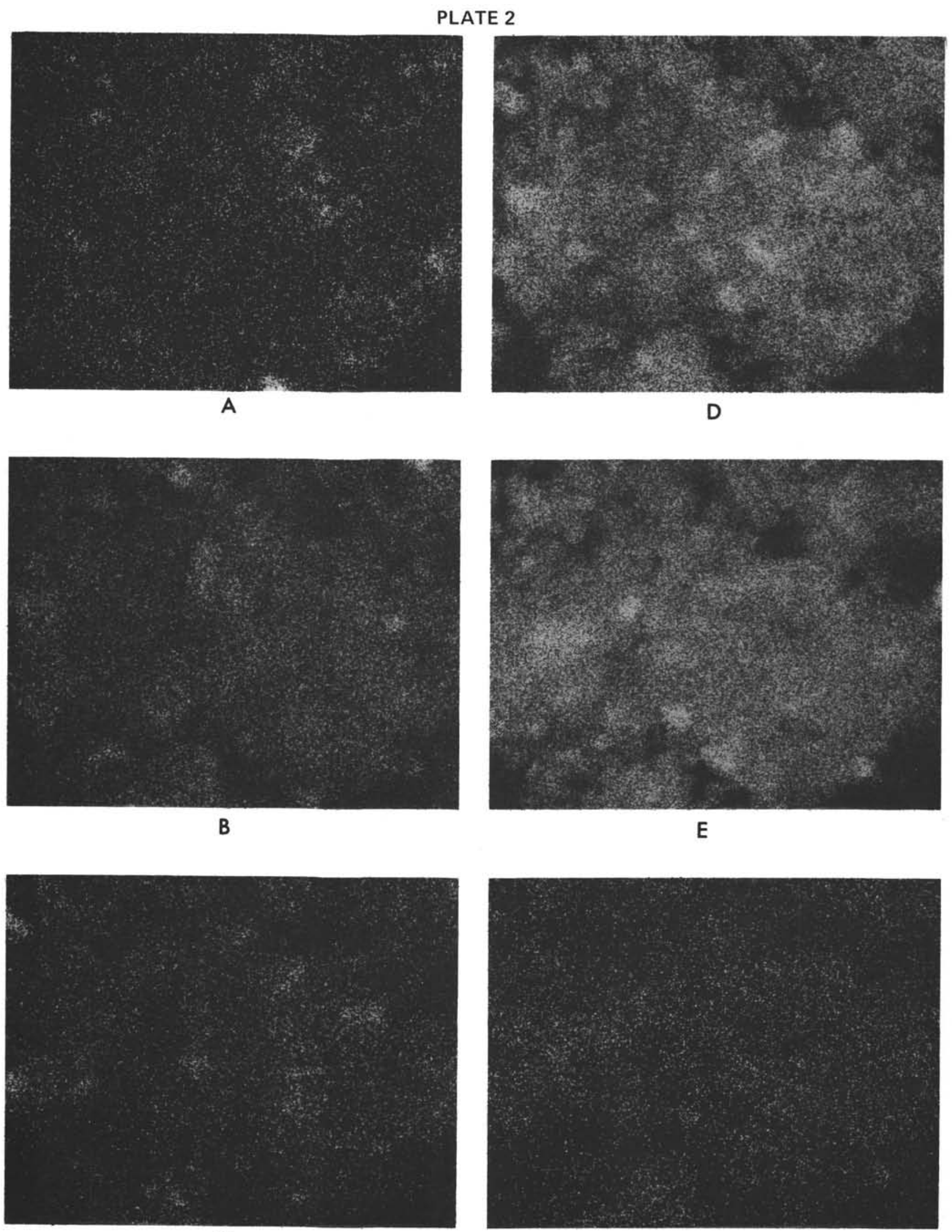
PLATE 3

SEM and EPMA images of Sample 196-2-1, 145-147 cm.

$$
\text { Length of bar: } 10 \mu
$$

Figure $1 \quad$ SEM image.

Figure $2 \quad$ Fe image.

Figure $3 \quad$ Mn image.

Figure $4 \quad \mathrm{Ca}$ image.

Figure $5 \quad \mathrm{~K}$ image 

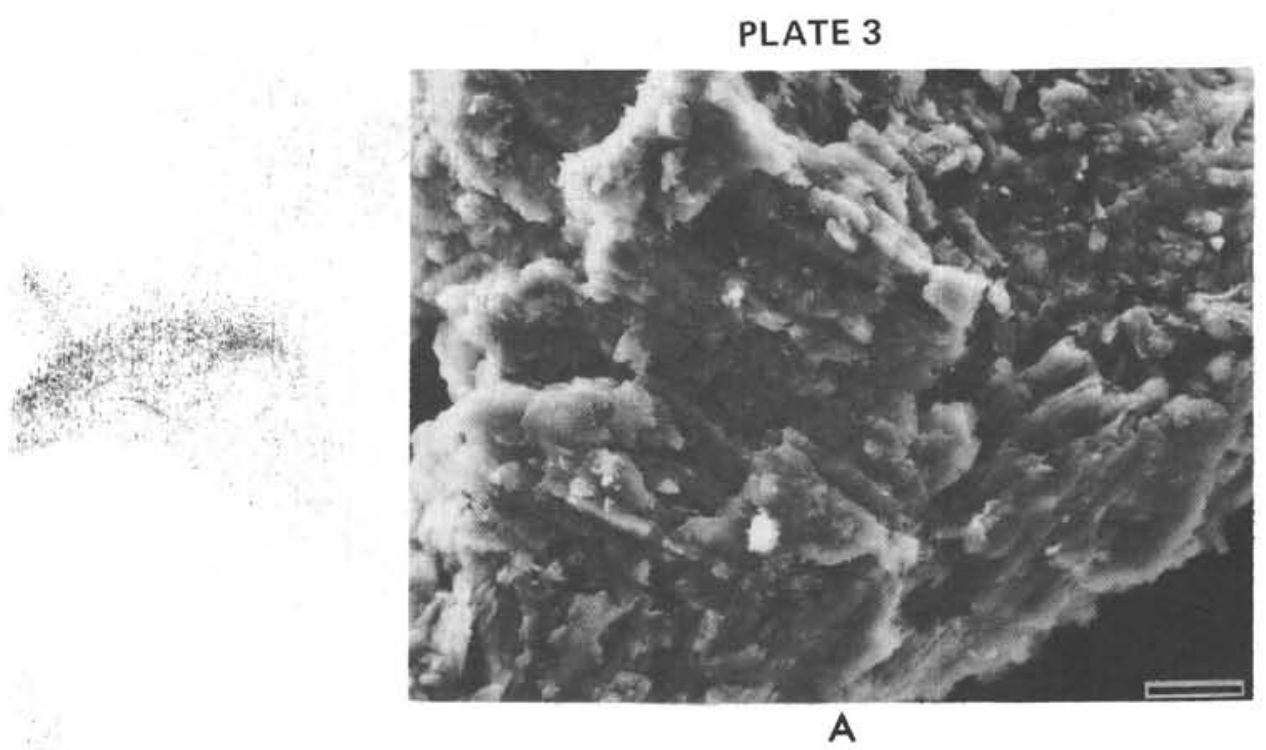

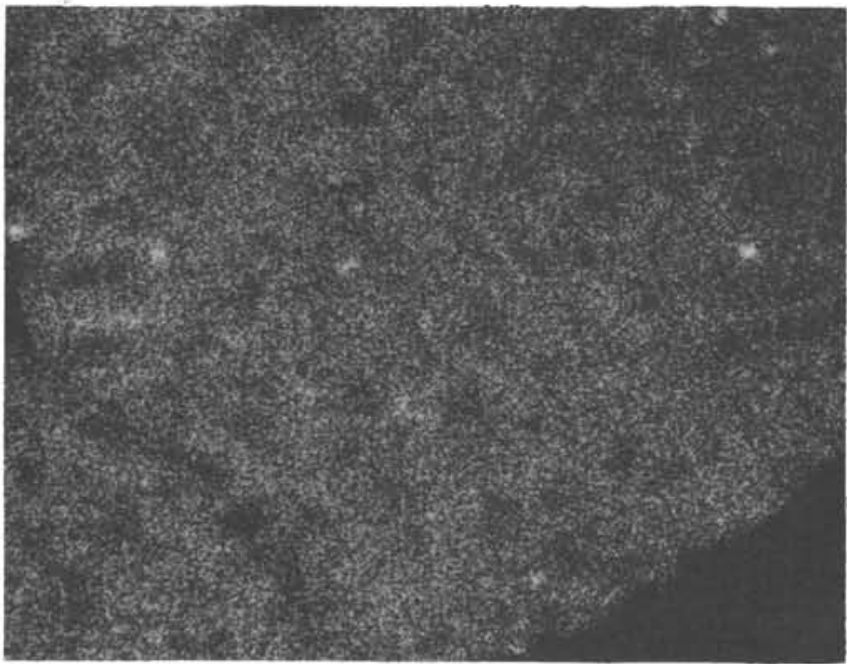

B

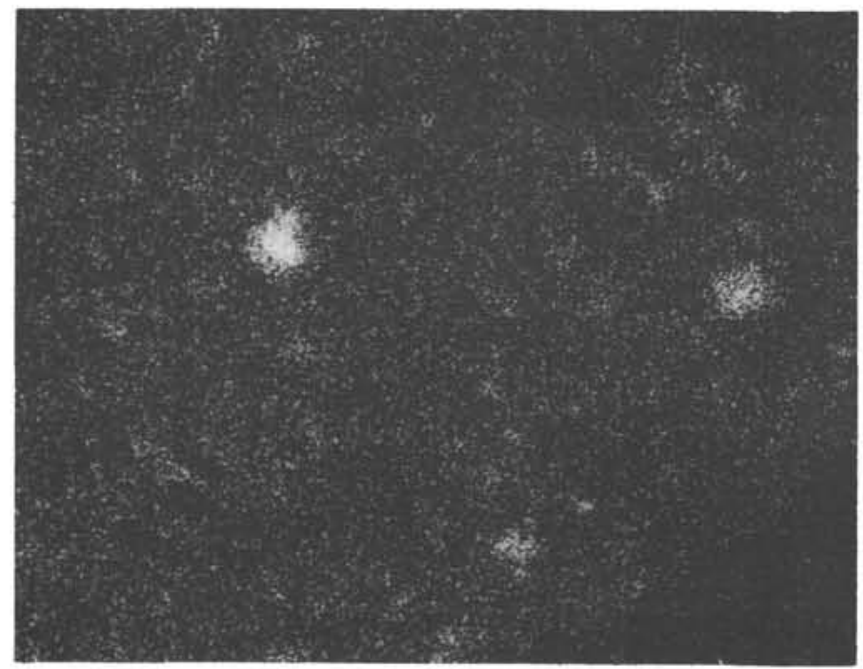

C
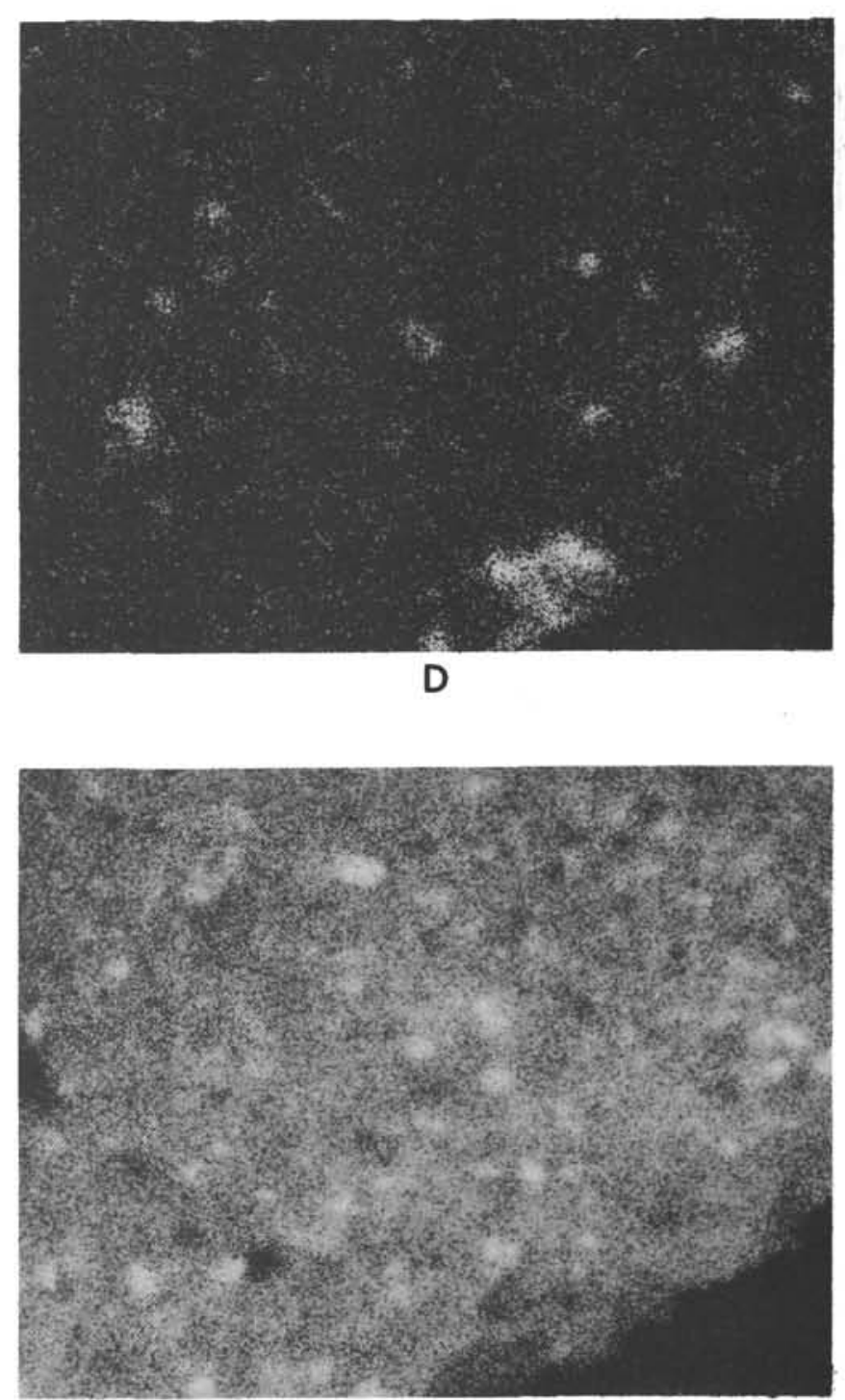

E 


\section{PLATE 4}

EPMA images of Sample 196-2-1, 145-147 cm.

Same magnification as in Plate 3, Figure 1.

Figure 1

Figure 2

Figure 3

Figure 4

Figure 5

Figure 6
$\mathrm{Cl}$ image.

Mg image.

Na image.

$\mathrm{Al}$ image.

Si image.

$\mathrm{O}$ image. 


\section{PLATE 4}

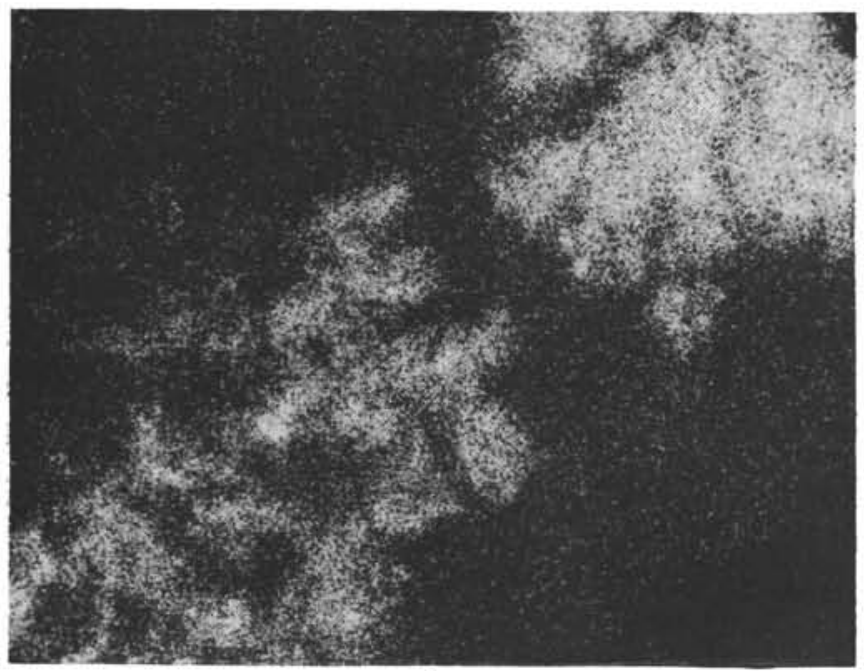

A

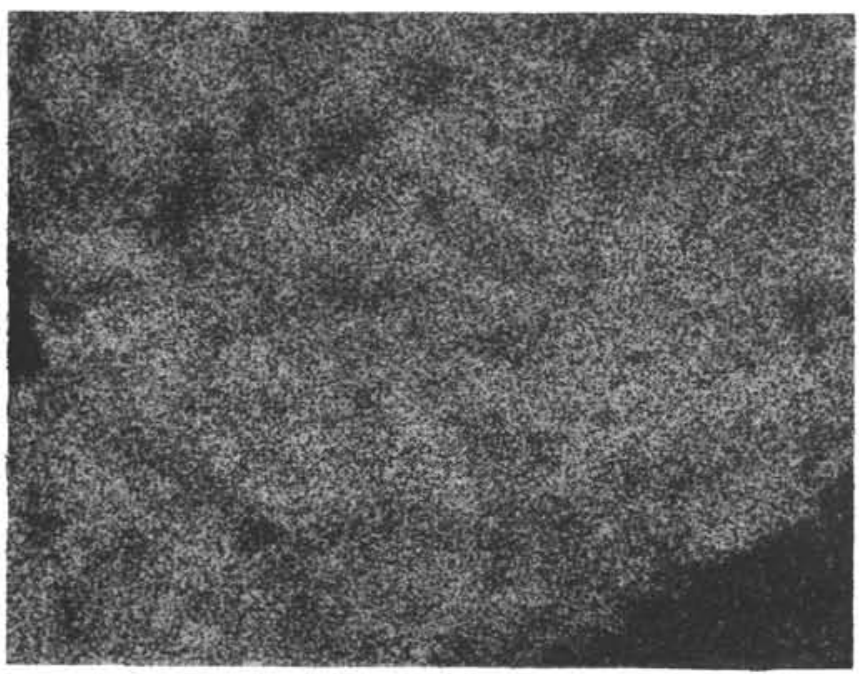

B

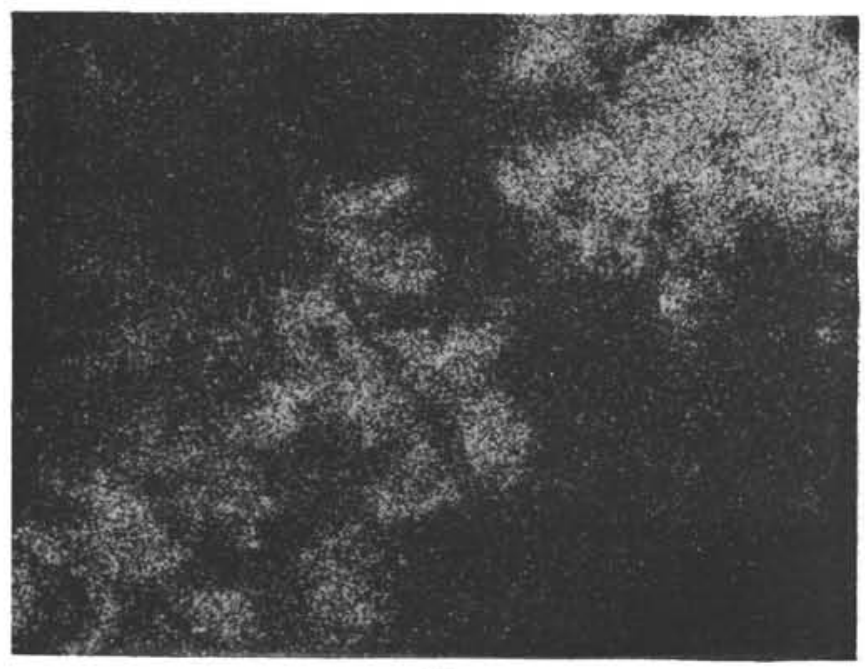

C

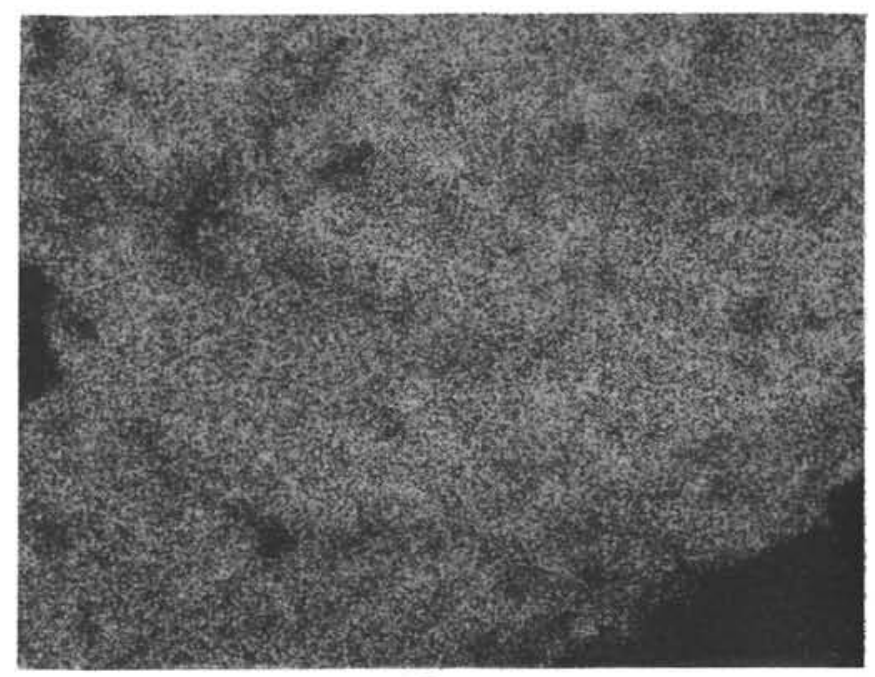

D

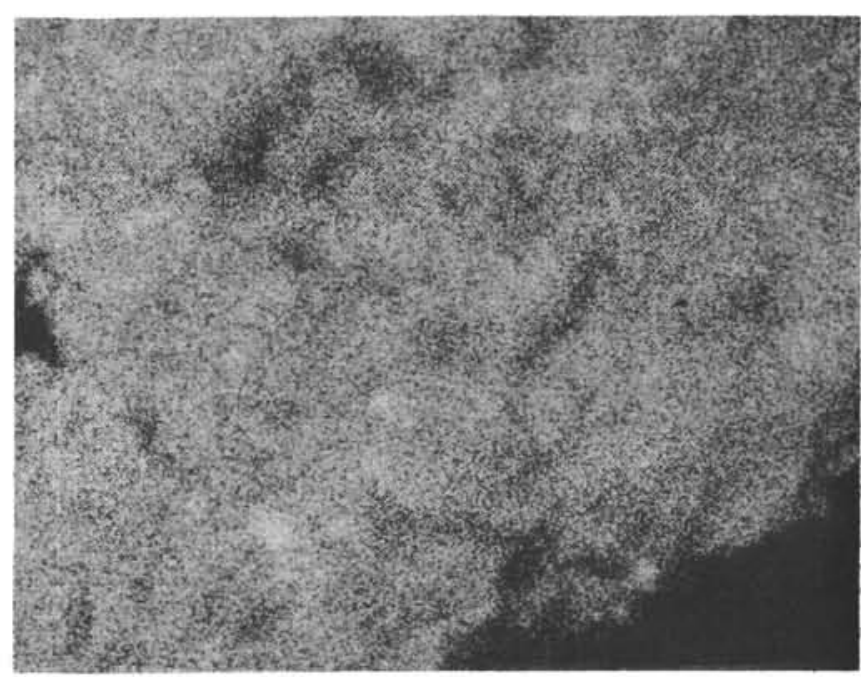

E

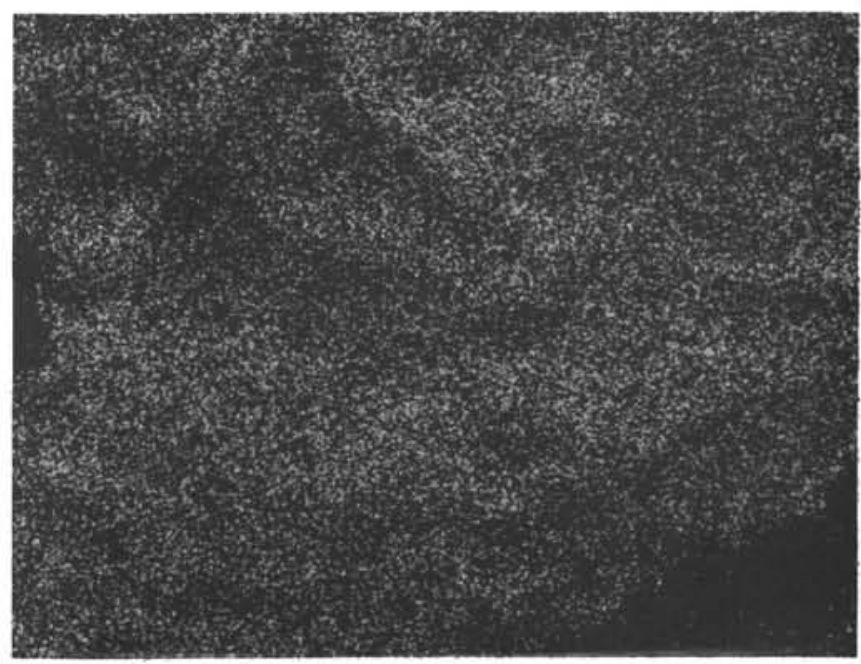

F 


\section{PLATE 5}

Figure 1 Photomicrograph showing clinoptilolite (elongated prismatic and acicular forms). Tabular prismatic forms may be plagioclase. Sample 199-4-3, 38-40 cm. Length of bar: $0.1 \mathrm{~mm}$, in open nicols.

Figure 2 SEM image showing concentrations of montmorillonite. Sample 199-5-1, 55-57 cm. Length of bar: $5 \mu$. 
PLATE 5
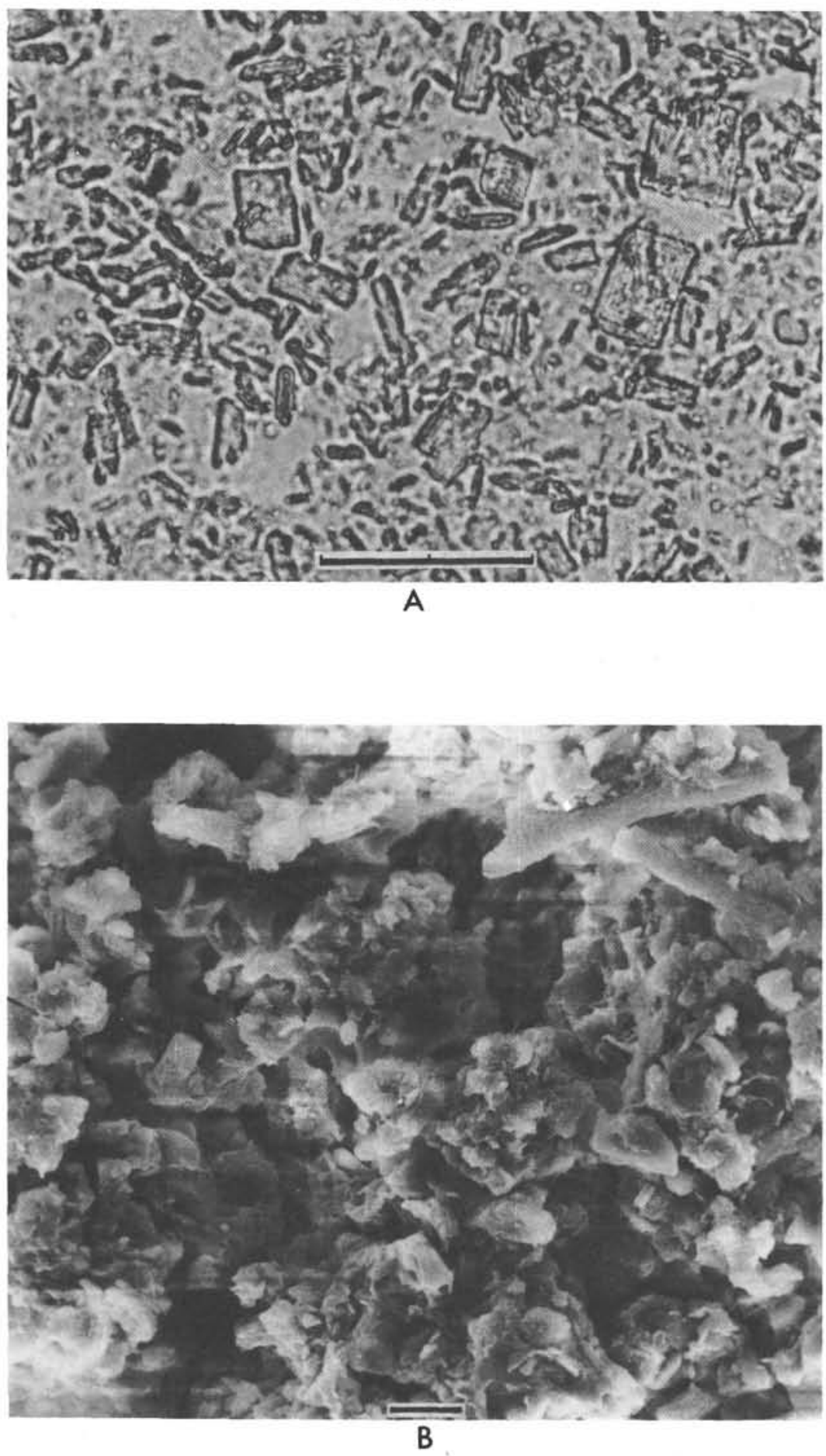